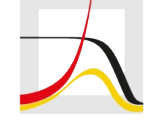

MAX PLANCK INSTITUTE

FOR DEMOGRAPHIC RESEARCH

Konrad-Zuse-Strasse 1 · D-18057 Rostock · Germany · Tel +49 (0) 3812081 - 0 · Fax +49 (0) 3812081 - $202 \cdot$ www.demogr.mpg.de

MPIDR Working Paper WP 2020-030 I August 2020

https://doi.org/10.4054/MPIDR-WP-2020-030

\title{
Leaders and Laggards in Life Expectancy among European Scholars from the Sixteenth to the Early Twentieth Century
}

Robert Stelter I stelter@demogr.mpg.de

David de la Croix

Mikko Myrskylä I sekmyrskyla@demogr.mpg.de

(c) Copyright is held by the authors.

Working papers of the Max Planck Institute for Demographic Research receive only limited review. Views or opinions expressed in working papers are attributable to the authors and do not necessarily reflect those of the Institute. 


\title{
Leaders and Laggards in Life Expectancy among European Scholars from the Sixteenth to the Early Twentieth Century*
}

\author{
Robert Stelter† David de la Croix ${ }^{\ddagger} \&$ Mikko Myrskylä ${ }^{\S}$
}

August 17, 2020

\begin{abstract}
When did mortality first start to decline, and among whom? We build a large, new dataset with more than 30,000 scholars covering the fifteenth to the early twentieth century in order to analyze the timing of the mortality decline and the heterogeneity in life expectancy gains among scholars in the Holy Roman Empire. The large sample size, well-defined entry into the risk group, and heterogeneity in social status are among the key advantages of the new database. After recovering from a severe mortality crisis in the seventeenth century, life expectancy among scholars started to increase as early as in the eighteenth century, or well before the Industrial Revolution. Our finding that members of scientific academies - an elite group among scholars - were the first to experience mortality improvements suggests that 300 years ago, individuals with higher social status already enjoyed lower mortality. We also show, however, that the onset of mortality improvements among scholars in medicine was delayed, possibly because these scholars were exposed to pathogens, and did not have germ theory knowledge that might have protected them. The disadvantage among medical professionals decreased toward the end of the nineteenth century. Our results provide a new perspective on the historical timing of mortality improvements, and the database accompanying our paper facilitates replication and extensions.
\end{abstract}

Keywords: Mortality dynamics, differential mortality, Holy Roman Empire, Thirty Years' War

JEL Classification numbers: J11, I12, N30, I20, J24

\footnotetext{
${ }^{*}$ We present the acknowledgments at the end of the paper.

${ }^{\dagger}$ Max Planck Institute for Demographic Research, Konrad-Zuse-Str. 1, 18057 Rostock, Germany and Leuphana University of Lüneburg, Institute of Economics, E-Mail: stelter@demogr.mpg.de, corresponding author.

${ }^{\ddagger}$ IRES/LIDAM, UCLouvain, Belgium and CEPR, London, UK. Email: david.delacroix@uclouvain.be.

$\S$ Max Planck Institute for Demographic Research, London School of Economics and Political Science, UK and University of Helsinki, Finland.
} 


\section{Introduction}

When the first mortality improvements occurred, and who benefited first from these gains, are among the key questions that arise in discussions of the first demographic transition. Understanding where and among whom mortality progress started is important for understanding the long-run dynamics of human well-being.

In this paper, we focus on the European scientific elite - i.e., scholars active at universities or academies of sciences. Observing each scholar's first appointment or nomination to a scientific institution helps to overcome common methodological issues in historical populations, as the appointment can be used to define the entry into the population at risk. More importantly, taking into account each scholar's scientific field and potential membership in an academy of sciences provides new insights into the role of medicine and social status in the process of mortality improvements. Finally, in a world where face-to-face communication was essential for both knowledge transmission and enhancement, the length of productive life among the elite was an important determinant of the extent to which members of the elite were able to influence their cultural and economic environments (de la Croix, 2017; Lucas, 2009).

Drawing on local evidence and data on specific social groups, historians and demographers have already shown that mortality gains were made in the seventeenth and eighteenth centuries. Hollingsworth (1977), for instance, has constructed mortality tables for the British nobility sampled from genealogical data. Vandenbroucke (1985) has provided vital statistics for the Knights of the Golden Fleece, an order that was started in 1430 by the Dukes of Burgundy, and that was maintained under the Habsburg rulers, the kings of Spain, and the Austrian emperors. Andreev et al. (2011) compared life expectancies of members of the British and the Russian academies of science. ${ }^{1}$ Cummins (2017) greatly extended existing demographic research on Europe's aristocracy by analyzing the longevity of the European nobility over a long period of time that covered several critical events, such as the Black Death and the Industrial Revolution. Longevity started rising as early as 1400, and continued to increase over the fifteenth century. However, this first phase has been observed in Ireland and the UK only and these findings are subject to considerable uncertainty. Even though the total sample size is large, when stretched over several centuries the uncertainty regarding any specific time point becomes large. This phase of longevity improvements was

\footnotetext{
${ }^{1}$ Edwards (2008), Winkler-Dworak (2008) and van de Kaa and de Roo (2007) also studied the longevity of members of academies of sciences, but with a more recent focus and much smaller sample sizes. Carrieri and Serraino (2005) and Hanley et al. (2006) compared the life expectancies of popes and artists; while van Poppel et al. (2013) examined the longevity of artists using information from the RKDartists database.
} 
followed by another after 1650 that has been observed throughout Europe in other studies as well (Hollingsworth, 1977; van Poppel et al., 2013, 2016). De la Croix and Licandro 2015 built a database drawn from the Index Bio-bibliographicus Notorum Hominum, which contains entries on famous people from about 3000 dictionaries and encyclopedias. They found no trend in adult longevity among individuals born before the second half of the seventeenth century. The findings of de la Croix and Licandro also suggest that permanent improvements in longevity preceded the Industrial Revolution by at least a century. The longevity of famous people increased steadily starting with the generations born in the 1640-1649 period, and grew by a total of around nine years in the following two centuries.

While the studies of de la Croix and Licandro (2015) and Cummins (2017) are important, they are not without weaknesses. In the populations they studied, who belonged to the sample and when people entered the population at risk could not be precisely defined. Some of the individuals in these populations, like famous martyrs, might have entered at death; while others, such as artists, may have entered post mortem; and still others, like members of royal families, entered at birth. In this paper, we present data that overcome such weaknesses, and use these data to reanalyze the timing of mortality improvements among the European elite. Furthermore, using information about relative status within the elite, we investigate whether differentials in socioeconomic position were already influencing mortality when secular changes in mortality first started, or whether this pattern is more recent. Finally, we exploit information about the scientific fields in which the scholars in our database were working to examine whether there were leaders or laggards by discipline. A particular focus of our analysis is on medicine, which may have had both positive and negative effects on longevity, depending on whether the benefits of medical knowledge offset the added hazards resulting from exposure to pathogens.

Our dataset, which is mainly based on university professor catalogs and lists of memberships in scientific academies, is constructed to clearly indicate who belonged to the population, and when each individual entered the risk population. An individual entered our population at risk as soon as he or she was appointed for the first time to any of the formal scientific institutions covered in our database. These institutions include all universities and technical universities established before 1800, as well as scientific academies located in the Netherlands and the territories of the Holy Roman Empire (HRE) as of 1648. Although its borders changed over time, the HRE occupied a large area of Central Europe from its founding in the Middle Ages until its dissolution in 1806. Furthermore, for most academic institutions in these territories, there are data sources that provide information on each scholar's dates of appointment, exit, birth, and death. 
Our sample, which covers more than 30,000 scholars born between the fourteenth and the nineteenth century, has several advantages. The sample allows us to consider left truncation and right censoring. Moreover, because the sample is large and focused on a well-defined population, we can use it to make precise estimates at the total population level, while also performing subpopulation- and age group-specific analyses.

Relying on the new data we collected, we aim to make two contributions to the literature. First, our analysis of scholars' life expectancy provides important new information about the dynamics and the timing of mortality changes before and during the Industrial Revolution. Our new estimations confirm that life expectancy started to improve in the middle of the eighteenth century - and, hence, before industrialization. Most of the deviations of our findings from existing estimates of mortality dynamics can be explained by differences either in the methods used or in how the role of social status is taken into account. In addition, our long time-series on mortality provide a novel finding on a notable mortality crisis around 1620-1650, which was likely driven by the Thirty Years' War. Studies that do not have a long observation window such as ours, which opens before the Thirty Years' War, could mistakenly conclude that the recovery from the crisis marked the start of secular mortality improvements.

Second, we shed light on mortality differences between groups by comparing members and non-members of scientific academies, as well as scholars in the medical field with scholars in other scientific fields. Members of scientific academies represent an elite within the elite. While it may be assumed that higher social status translates into mortality advantages, the evidence on the association between social status and mortality is mixed. Hollingsworth (1977) and Vandenbroucke (1985) found that mortality reductions occurred as early as in the seventeenth century among the nobility, and thus showed that longevity improvements among the upper social classes anticipated the overall rise in life expectancy by at least a century. By contrast, de la Croix and Licandro (2015) found that in the seventeenth and eighteenth centuries, mortality reductions took place not just in the leading countries, but almost everywhere in Europe. Their findings also indicated that these mortality improvements were not dominated by any particular occupation. ${ }^{2}$ In a literature review, Bengtsson and van Poppel (2011) concluded that the impact of social status varied across areas, time periods, and contexts. Meanwhile, we observe that among members of academies of sciences, mortality gains accelerated around the time when life expectancy started to increase sustainably. This finding suggests that as early as 300 years ago, scholars with higher social

\footnotetext{
${ }^{2}$ Furthermore, Bengtsson and Dribe (2011) found evidence of the late emergence of a mortality advantage in Sweden. Using data from Geneva, Schumacher and Oris (2011) documented an advantage among the higher classes that ended in the seventeenth and eighteenth century.
} 
status enjoyed lower mortality.

The role of the medical profession in these trends is less clear. As the germ theory of disease was not well-developed before the second half of the nineteenth century, it may be assumed that individuals working in the medical profession prior to that time received little protection from their medical knowledge, while also being exposed to elevated infection risks (de la Croix and Sommacal, 2009). It is, therefore, possible that medical professionals had a net disadvantage. For example, to protect against the bubonic plague, people used beaklike masks that did little more than protect against the smells - which were, at that time, believed to be the main disease vector. Thus, for medical professionals, the combination of increased exposure to sick people and the lack of medical knowledge may have been lifethreatening. Our results partially support this reasoning: while we find only weak evidence of a systematic disadvantage among medical professionals before sustained improvements in longevity began, we show that once mortality improvements started, medical professionals experienced life expectancy gains later than the rest of the scientific elite.

\section{Scholars in the Holy Roman Empire}

\subsection{Universities and Scientific Academies}

Our dataset collects information on scholars who were active in the Holy Roman Empire (HRE). The Empire was founded around 962 as Otto I sought to revive the Roman Empire by laying claim to the imperial cult of Rome. Thus, the HRE existed long before the first universities appeared in this area. While the borders of the Empire changed over its almost 850 years of existence, its elective monarchy unified the Germanic population and other peoples over this long period through a unique set of cultural and political arrangements. In the nineteenth and twentieth centuries, following the dissolution of the Empire in 1806, the territory of the German state declined substantially, and the populations of Central Europe shifted. To take advantage of the relatively stable institutional set-up provided by the HRE, we focus on populations living within the Empire's 1648 borders and in the Netherlands. As shown in gray in Fig. 1, the territories of the Empire correspond to the current territories of Austria, Belgium, Germany, Lichtenstein, Luxembourg, Slovenia, and the Czech Republic; as well as small parts of Croatia, France, Italy, Poland, and Switzerland. The territories that made up the Netherlands are depicted in light gray. 


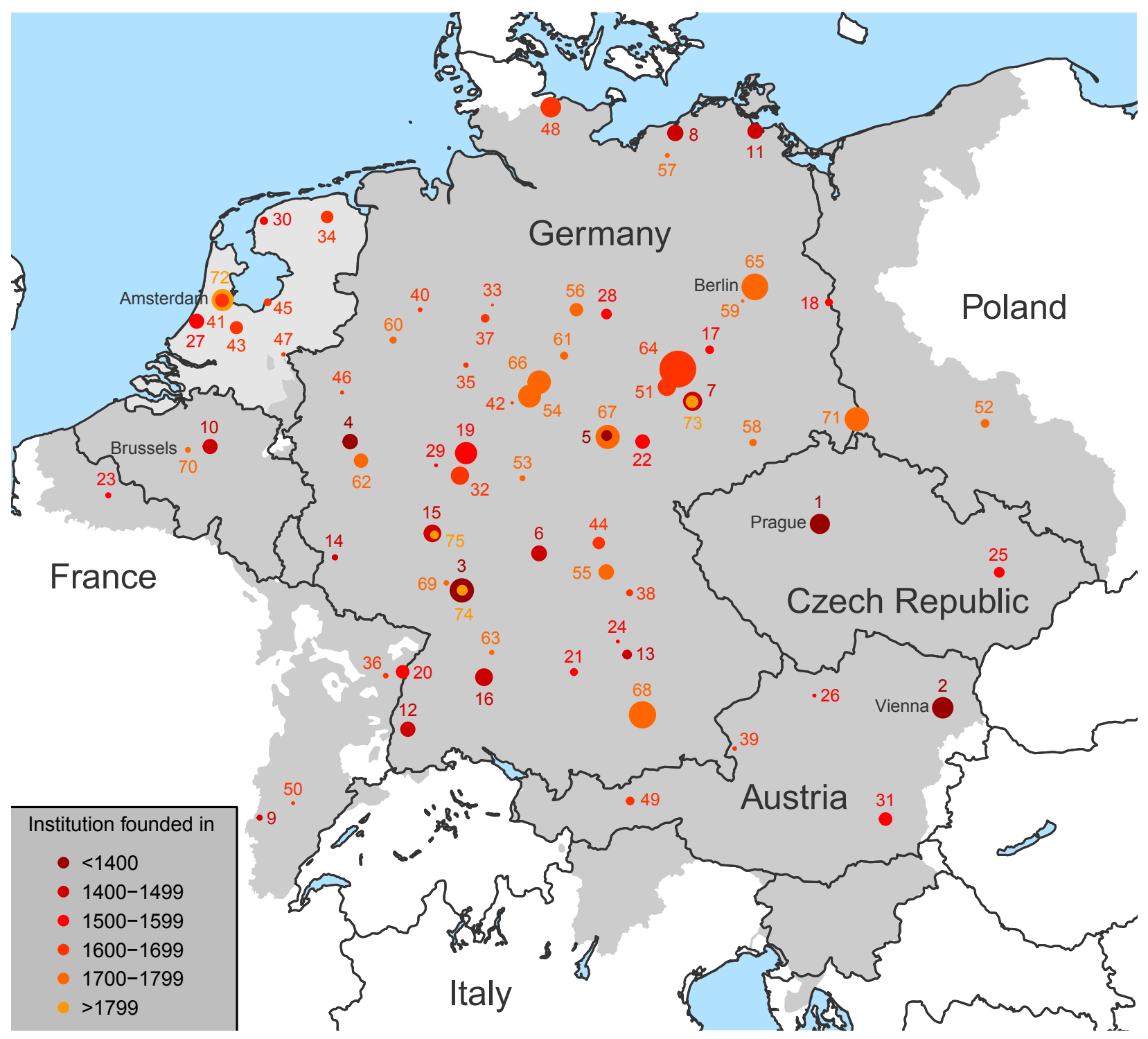

Fig. 1. Universities and academies in the territories of the Holy Roman Empire and the Netherlands

Universities and scientific academies located in the 1648 territories of the Holy Roman Empire (gray) and of the Netherlands (light gray). The area of the circle is proportional to the number of observations of the institution, and the color indicates the century of foundation. Numbers 1-63 mark universities sorted by year of foundation, and numbers 64-75 mark academies of sciences. For an entire list of the corresponding institutions, see Tab. A1 in Appendix A.1.

Scholars might have been active in universities, academies of sciences, or courts. Since the first two types of institutions are quantitatively the most important, we define scholars as individuals who were active in one of these two types of scientific institutions, and we restrict our sample to scholars who were born before 1900. This precise demarcation of our population should not cover up the fact that many things have changed since the creation of 
Prague university in 1348. Rules for granting degrees, such as a doctoral degree, or the social status of university professors changed, for instance, after the Humboldt reform (Schimank and Winnes, 2000). Salaries prior to the modern period were often low, paid in kind, or not paid at all, e.g. during the Thirty Years' War (Vandermeersch, 2003; Klinge, 2004; Langer, 2011). Still, considering a changing environment, we are as close as possible to a well-defined population. Any other professions would face similar changes; even the nobility.

We include in our database scholars who were appointed to universities that were founded before 1800. Based on Frijhoff (1996) and Steiger (1981), we identified 63 such universities. Universities that were founded later than 1800 are excluded, both because the HRE ended in 1806, and because the European university underwent radical changes around this time. A large number of universities disappeared at the beginning of the nineteenth century. In Germany, for instance, 18 out of 34 universities were closed (Charle, 2004). More importantly, universities founded in the nineteenth century followed a new university model shaped by the Humboldt reform (Schimank and Winnes, 2000). Thus, because our focus is on older universities, our results are not affected by the significant changes that occurred around 1800.

Still, the 63 older universities were rather heterogeneous along several dimensions. Figure 1 illustrates the spatial distribution of these institutions, and the number of scholars related to each institution by the area of the circle. Established in 1348, the University of Prague (1) was the oldest university in the HRE; followed by the University of Vienna (2) founded in 1365 and the University of Heidelberg (3) founded in 1386. The University of Bonn (62) and Karl's High School (63) were the two youngest universities. In addition, four more applied universities, such as the Freiberg University of Mining and Technology (58), were among the institutions established in the eighteenth century. In the Dutch territories, university education started in 1575 with the establishment of Leiden University (27). While a total of seven universities were founded in the Netherlands before 1800, the University of Nijmegen (46) educated students only for a very limited number of years, and the universities in Franeker (31) and Harderwijk (45) closed near the end of the Napoleonic era. Several universities in the HRE met the same fate. These universities were closed either in response to geopolitical movements, as was the case in Cologne (4) and Erfurt (5); or as a result of secularization, as was the case in Bamberg (44) and Dillingen (21).

Figure 1 includes the 12 academies of sciences (sometimes combined with arts) for which we have data. While other academies existed during the time period we cover, these institutions were, on average, of lesser importance. ${ }^{3}$ Over the course of history, large numbers of scientific

\footnotetext{
${ }^{3}$ For an overview on academies, see the Scholarly Societies Project
} 
academies have appeared, and, in some cases, have later disappeared. By far the most important of the scientific academies we cover is the Collegium Naturae Curiosorum, which was established in 1652, and is better known as Leopoldina (64). The Bavarian Academy of Sciences and Humanities (68) and the Royal Netherlands Academy of Arts and Sciences (72) were also well-known. The latter academy was founded in 1808. We include this institution because academies did not undergo the same structural changes as universities. Thus, there was no reason to exclude these more recently established institutions.

\subsection{Data and Sources of the Dataset}

Our sample of scholars was compiled using a range of sources. We assign the institutions to four categories based on data availability and the data sources used. In the first category are the institutions for which we have (almost) complete data. In this optimal case, we rely on two types of high-quality sources: existing online professor catalogs, such as the catalogus professorum lipsiensium; or books that provide biographical information on professors, like Drüll $(1991 ; 2002 ; 2009 ; 2012)$ on the University of Heidelberg. Overall, the first category includes 23 universities and 10 academies of sciences. Our sources of data for these academies include official lists of members that were provided either directly by the academy, or by their publications.

For other universities, the existing catalogs do not capture either the whole time span or all faculties. Since these sources still provide highly reliable information, they are included in the second category, which is made up of institutions with partially complete data. For instance, Günther (1858) only provides information on University of Jena professors up to the university's 300th anniversary in 1858; while Flessa (1969) only provides information on medical faculty professors in Altdorf. In addition to 15 universities, the Royal Academy of Sciences, Letters and Fine Arts of Belgium is included in this second category.

The sources we use for the institutions in the third category enabled us to further complete our list of scholars. The available data for the institutions in this third category are less complete. For 12 universities, we reconstructed as many observations as possible from a variety of sources. These sources include lists on Wikipedia, which are, whenever possible, backed-up with additional sources, like the Deutsche Biographie. ${ }^{4}$ For example, we collected

(http://www.references.net/societies/).

${ }^{4}$ The reliability of Wikipedia information is not always easy to validate. Less than $2 \%$ of our observations are solely based on Wikipedia. We have checked that all our results are robust to the exclusion of all institutions without traditional sources; for details, see section 3.4 and the online material. 
data on scholars from the University of Erfurt (5) and Brandenburg University in Frankfurt (18) using this strategy. The remaining scientific academy, the Palatinate Academy of Sciences in Mannheim (68), is also assigned to the category non-complete data.

The remaining 14 universities are in the last category, scattered data. Their members are captured either via other universities of a higher class or using data collections, like Fischer (1978). The oldest university in this category is the University of Trier (14). ${ }^{5}$

By combining the data from the sources in all four categories and removing duplicates, we gathered information on 33,498 scholars. This population forms our total sample of scholars who were born before 1900, and who were active in the defined universe of universities and scientific academies. Individuals entered the population of scholars at the time when they were first appointed. Individuals exited the population at death, if this event is observed. If death is not observed, they are censored at the last exit from one of our institutions.

\subsection{Data Quality}

Given that our historical data cover more than four centuries, some uncertainty about these data is understandable, particularly at the very beginning of our time span. In this section, we discuss two potential caveats: missing values and heaping in the years of birth and death.

Table 1 summarizes important descriptive statistics. The total sample of scholars declines from 33,498 to 31,176 if we only consider individuals for whom the year of appointment and of death or exit are known. The sample further shrinks to 27,842 if we only include individuals for whom their ages at the events are known; we use this as the baseline sample for our mortality estimations. Most cases for which the ages are unknown suffer from multiple missings. In $96.2 \%$ of cases in which we observe age, we also observe death. The share of right-censored cases for which death is unknown increases slightly for the most recent time periods because our data sources, such as Conrad (1960) for the University of Tübingen, are from a time when many of the scholars were still alive. We know the age at death for scholars who died after the date of publication only if we find them in other sources.

\footnotetext{
${ }^{5}$ Table A1 in Appendix A.1 provides complete overviews of the categories and sources of all 75 institutions.
} 
Tab. 1: Observations by year of appointment

\begin{tabular}{|c|c|c|c|c|c|c|c|c|c|}
\hline \multirow[b]{3}{*}{ Year } & \multirow{3}{*}{$\begin{array}{c}\text { All } \\
\text { appointments* } \\
\text { N } \\
\end{array}$} & \multicolumn{8}{|c|}{ Appointments with known age ${ }^{* *}$} \\
\hline & & \multirow[b]{2}{*}{$\mathrm{N}$} & \multicolumn{2}{|c|}{ Mean age at } & \multirow{2}{*}{$\begin{array}{c}\text { Death } \\
\text { observed, \% }\end{array}$} & \multicolumn{2}{|c|}{ University appointments } & \multicolumn{2}{|c|}{ Academy appointments } \\
\hline & & & appointment & death & & Total & Medicine, $\%$ & Total & Medicine, $\%$ \\
\hline$<1400$ & 217 & 46 & 37.5 & 63.3 & 97.8 & 46 & 2.2 & 0 & - \\
\hline $1400-1449$ & 616 & 87 & 32.5 & 64.2 & 98.9 & 87 & 8.0 & 0 & - \\
\hline $1450-1499$ & 607 & 162 & 33.0 & 62.5 & 97.5 & 162 & 6.2 & 0 & - \\
\hline $1500-1549$ & 770 & 349 & 32.3 & 60.5 & 98.6 & 349 & 8.0 & 0 & - \\
\hline $1550-1599$ & 998 & 719 & 33.3 & 60.6 & 97.4 & 719 & 11.7 & 0 & - \\
\hline $1600-1649$ & 1085 & 893 & 34.0 & 58.8 & 96.9 & 891 & 10.7 & 2 & 100.0 \\
\hline $1650-1699$ & 1662 & 1458 & 33.9 & 60.2 & 96.9 & 1213 & 7.9 & 245 & 84.5 \\
\hline $1700-1749$ & 2401 & 2194 & 34.8 & 62.0 & 97.9 & 1497 & 7.5 & 697 & 42.0 \\
\hline $1750-1799$ & 3468 & 3228 & 35.7 & 64.1 & 97.1 & 1556 & 11.6 & 1672 & 28.9 \\
\hline $1800-1849$ & 4506 & 4306 & 37.6 & 67.0 & 98.6 & 1516 & 17.2 & 2790 & 20.0 \\
\hline 1850-1899 & 5920 & 5802 & 38.2 & 69.2 & 98.2 & 2187 & 22.2 & 3615 & 19.6 \\
\hline 1900-1929 & 5845 & 5730 & 40.3 & 72.0 & 92.5 & 2962 & 26.9 & 2768 & 18.6 \\
\hline$\geq 1930$ & 3081 & 2868 & 53.9 & 76.9 & 92.6 & 1258 & 24.6 & 1610 & 25.7 \\
\hline All & 31176 & 27842 & 39.0 & 67.8 & 96.2 & 14443 & 17.1 & 13399 & 23.7 \\
\hline
\end{tabular}

* Used in analyses presented in Fig. 3. ${ }^{* *}$ Used in analyses presented in Fig. 4-7. 
In the 1400-1700 time span, the mean age at first appointment was rather stable, at between ages 32 and 35. In the more recent period, the mean age at first appointment increased, reaching as high as age 40 in the early twentieth century. By contrast, the mean age at death followed a u-shaped pattern. Starting at around age 64 for scholars appointed in the early fifteenth century, it declined to age 59 among those who entered the dataset in the first part of the seventeenth century. The mean age at death increased to more than 70 years for scholars appointed at the onset of the twentieth century.

The population of scholars was heterogeneous along several dimensions, two of which we focus on here. First, to explore the role of medical knowledge, we distinguish between scholars with and without a medical background. To identify these individuals, we checked whether the scholars in our sample studied medicine, held a PhD in medicine, were active in a medical faculty, held a chair in medicine, were active in a field of research linked to medicine, or belonged to a class of medicine in an academy of sciences. Second, we distinguish scholars by the scientific institutions to which they belonged. Members of academies of sciences represent a sort of elite within the knowledge elite. Because these scholars had more scientific achievements and better access to networks than non-members, they likely had higher social status. Thus, we use memberships in academies as social status indicators that we can link to mortality dynamics.

Numbers for the four groups of scholars are shown in Tab. 1: scholars active only in universities, and among them those linked to the medical profession; and scholars affiliated with an academy, and among them those linked to medicine. In total, our data cover 14,443 scholars affiliated with a university only, and 13,399 scholars with an academy affiliation. While only a small percentage of scholars appointed before the seventeenth century were active in the field of medicine, this share had increased to one-quarter by the end of the follow-up.

Uncertain or unknown years of birth and death may be approximated by years ending on zero or five. While the use of this approach might reduce the share of missing values, it could cause birth and death year heaping in our data. To check the scale of the heaping, we follow the concept of the Whipple-Index (Hobbs, 2004) and compare the observed number of birth years ending on zero or five with the overall number of births in the same period. Figure 2a displays the shares of births per fifty-year period ending on zero or five. If there was no heaping, we would expect $20 \%$ of the birth years to end with zero or five. We observe that more than half of birth years ended on zero or five in the fifteenth century. However, data quality improves rather quickly thereafter: by the beginning of the seventeenth century, the share was already close to 0.2 . If we restrict the sample to scholars without an uncertain year of birth, the data quality improves significantly, and becomes acceptable starting in the 
fifteenth century. ${ }^{6}$

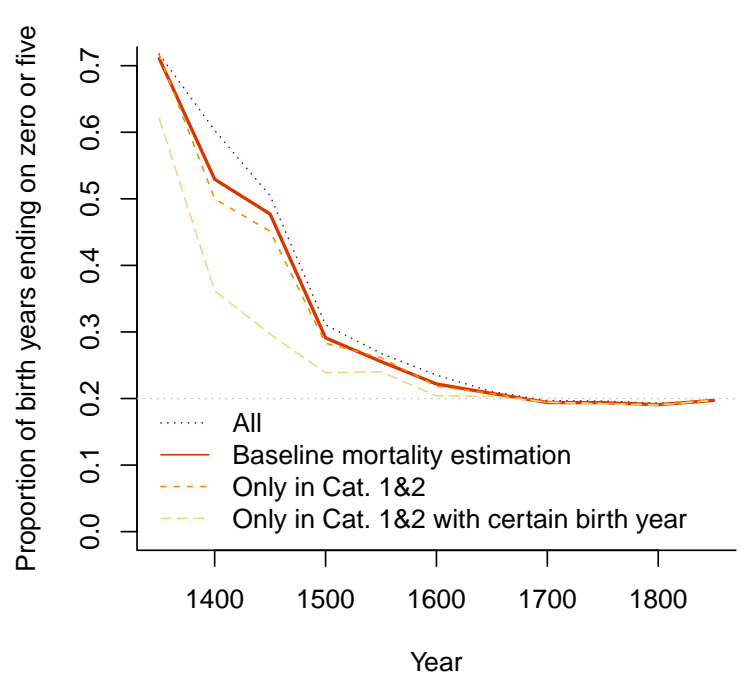

(a) Proportion of birth years ending on zero or five

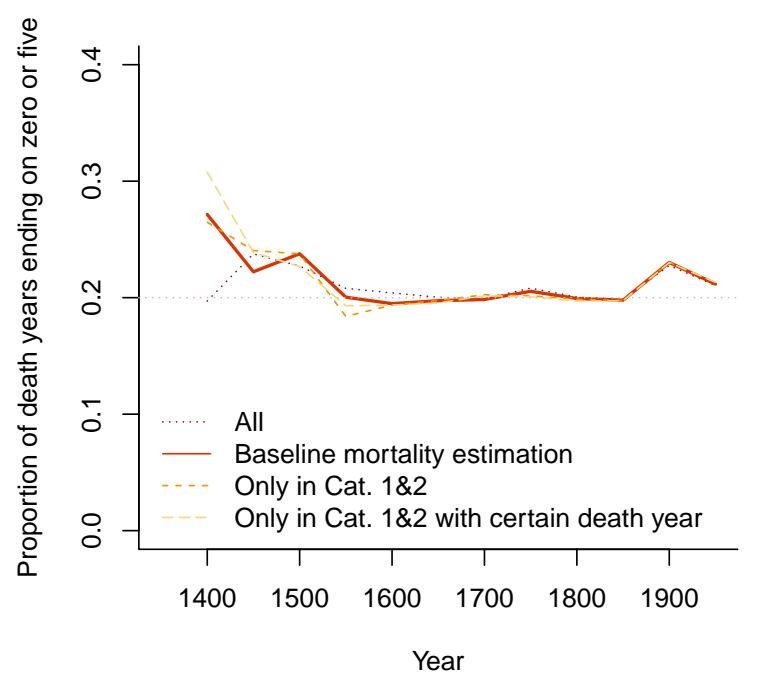

(b) Proportion of death years ending on zero or five

Fig. 2. Birth and death year heaping

All includes all scholars with either a known year of birth or a known year of death. Baseline mortality estimation restricts the sample to the 27,769 scholars with known ages at appointment and at death or exit used in the estimations of life expectancy (Column 2 in Tab. 1). Only in Cat. 1 \& 2 further limits the sample to scholars with data from categories 1 (almost complete data) and 2 (partially complete data). Finally, Only in Cat. 1 \& 2 with certain death or birth year excludes all observations with the year of birth or death marked as approximated in the sources.

We observe less year heaping for mortality data than for birth data. In previous centuries, birth data was reliably recorded for some families, like those of scholars, clergyman, or nobles; whereas the birth dates of children in ordinary families were less well-documented, or were approximated in the data sources. However, when an individual was appointed to one of our institutions, he or she likely became sufficiently important to have his or her death date recorded. Hence, the share of death years ending on zero or five is generally much closer to 0.2 (Fig. 2b). Furthermore, the observed heaping is not always due to poor data quality; e.g., the peak in 1900-1949 (Fig. 2b) is driven by the exceptionally high mortality at the end of World War II.

Significant birth year heaping and some death year heaping is found at the beginning of our observation window. Whether this heaping biases any of our results depends on whether the years are systematically adjusted upward or downward. This is difficult to evaluate

\footnotetext{
${ }^{6}$ For more detailed information, see Fig. A1-A5 in the supplementary material.
} 
directly. As an indirect robustness check, we have replicated our analyses while excluding all individuals with a year of birth or death ending in zero or five. The results are robust to this check, see Section 3.4 .

\subsection{The Population of Scholars}

The scholars' years of first appointment and of death - or of last exit if the year of death is missing - enables us to calculate the dynamics of the total number of scholars. Figure 3a plots the 25-year moving averages of the first appointments, deaths, and deaths or exits due to censoring. The figure shows a general increasing tendency in appointments that was followed by a comparable increase in deaths.

The flows displayed in Fig. 3a are turned into stocks of scholars in Fig. 3b. This figure shows three periods marked by the trend line imposed on the total stock of scholars. First, before 1618, appointments exceeded outflows; except for very short periods in the middle of the fifteenth century. The number of scholars grew by an average of $0.5 \%$ per year, and, hence, at the same pace as the total population. ${ }^{7}$ Second, around 1618, appointments started to decline and continued to decline until approximately 1648. In the 1618-1648 period, outflows exceeded appointments, and for a quarter of a century, the population of scholars decreased by around $0.6 \%$ annually. Third, the appointments bounced back starting around 1648. From that year until around 1900, appointments strongly exceeded deaths, and the population of scholars grew at an annual rate of $0.8 \%$.

After the first academy was founded, the shares of the sample belonging to universities and academies were soon balanced. After 1800, half of the sample were active in at least one academy of sciences. However, to avoid small sample noise - and given that before the eighteenth century, the Leopoldina was the only academy to which scholars could be appointed - we limit our investigation of the link between social status and mortality to the periods after 1700, when the second academy was established. Before 1700, we can only compare the Medicine $\&$ Universities and Non-medicine $\&$ Universities groups. However, since Fig. 3b shows that only a few scholars were engaged in medicine before the seventeenth century, we limit our investigation of mortality dynamics to the period after 1600 .

\footnotetext{
${ }^{7}$ Pfister and Fertig (2010) documented an average growth rate of around 0.5\% p.a. for the German population.
} 


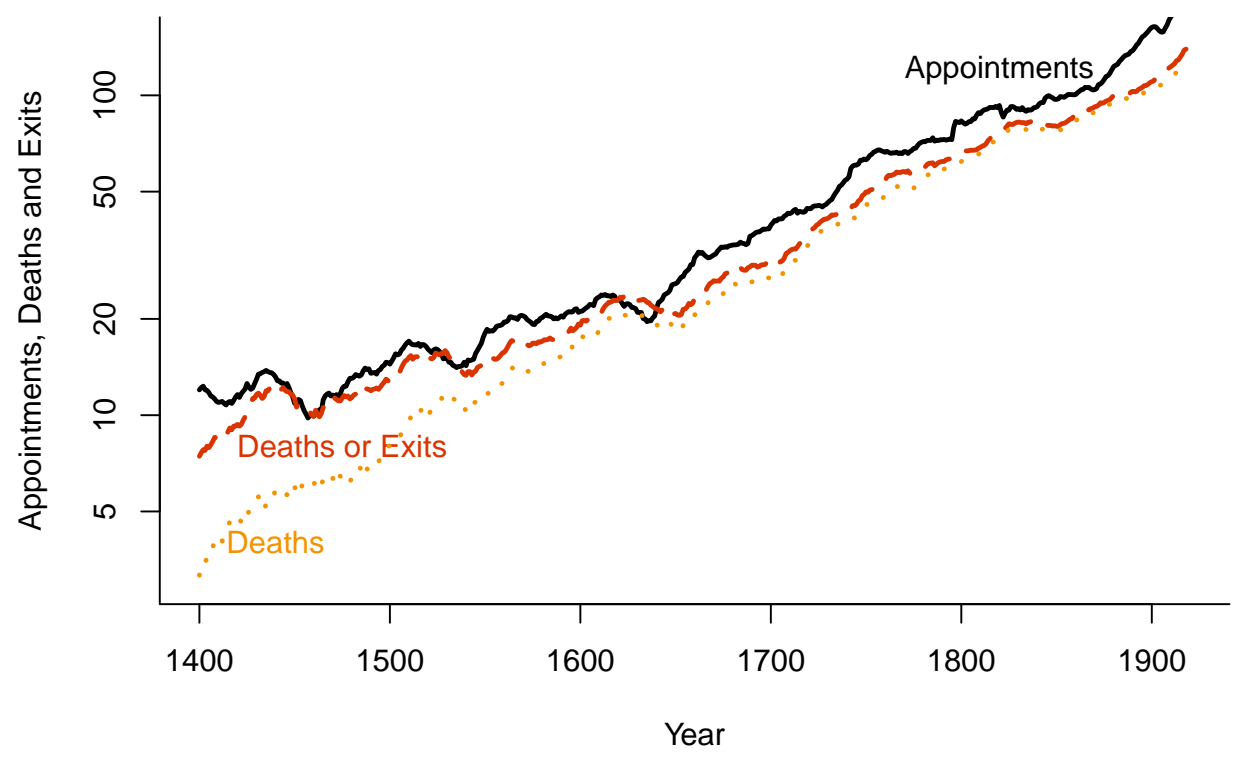

(a) 25-year moving averages in Appointments, Deaths, and Deaths or Exits

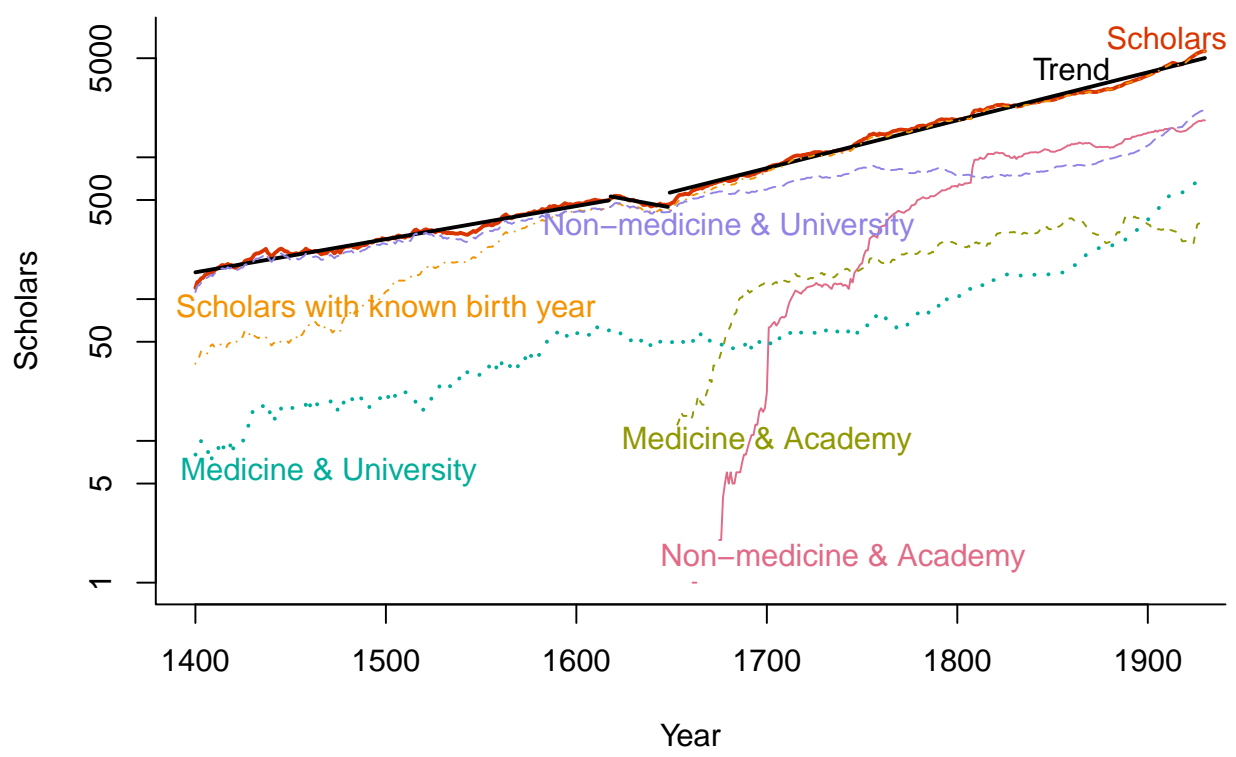

(b) The number of scholars

Fig. 3. The dynamics in the population of scholars 
The trends we observe in the numbers of appointments and exits/deaths - and, hence, in our total population - capture different developments. First, the appointment numbers were sensitive to the size of each institution. Second, the appearance and disappearance of universities and academies - such as the closing of a number of institutions after the Napoleonic Wars - altered the number of appointments and exits. As we lack exhaustive sources for all of the institutions in our sample, a certain number of scholars within each institution might be missing. Thus, sample selection is a third factor that could affect our results. Missing or uncertain information within the sample of scholars on the years of events is a fourth factor. Figure $3 \mathrm{~b}$ provides some insights into the role of missing events. If we limit our population to scholars whose year of birth is known, the initial population is smaller, and grows faster in the early period. As ages are required to estimate mortality, further investigations rely on this smaller sample.

\subsection{Methods}

We estimate age-specific mortality rates and life expectancy at age 30 for the population of scholars, and for the subpopulations. We use age 30 as the starting age for life expectancy because for younger ages, the sample of scholars becomes very small. ${ }^{8}$ Due to the limited sample size in the early years, we first smooth the death rates over age and time (Camarda et al., 2012). We then compute period life expectancy at age 30 over rolling 25-year intervals, and apply Monte Carlo simulations to estimate the corresponding confidence intervals (Chiang, 1984; Andreev and Shkolnikov, 2010). In the following, years mark the middle of the 25-year intervals. The contributions of each age to changes in life expectancy are decomposed by the stepwise replacement algorithm from Andreev and Shkolnikov (2012), which is described in Andreev et al. (2002).

\section{Findings}

\subsection{Life Expectancy}

Three clear patterns emerge in life expectancy at age 30 for the population of scholars (Fig. 4). First, there was no systematic improvement in life expectancy among scholars before the middle of the eighteenth century. Second, we find evidence of a sharp decline in life

\footnotetext{
${ }^{8}$ For a more detailed discussion, see Appendix A.3.1 in the supplementary material.
} 
expectancy in the first half of the seventeenth century. Scholars' life expectancy at age 30 declined from more than 30 to less than 27 years. Third, we see that thereafter, a phase of steady improvements in mortality began. Between 1750 and 1900, conditional life expectancy increased by around 7.5 years.

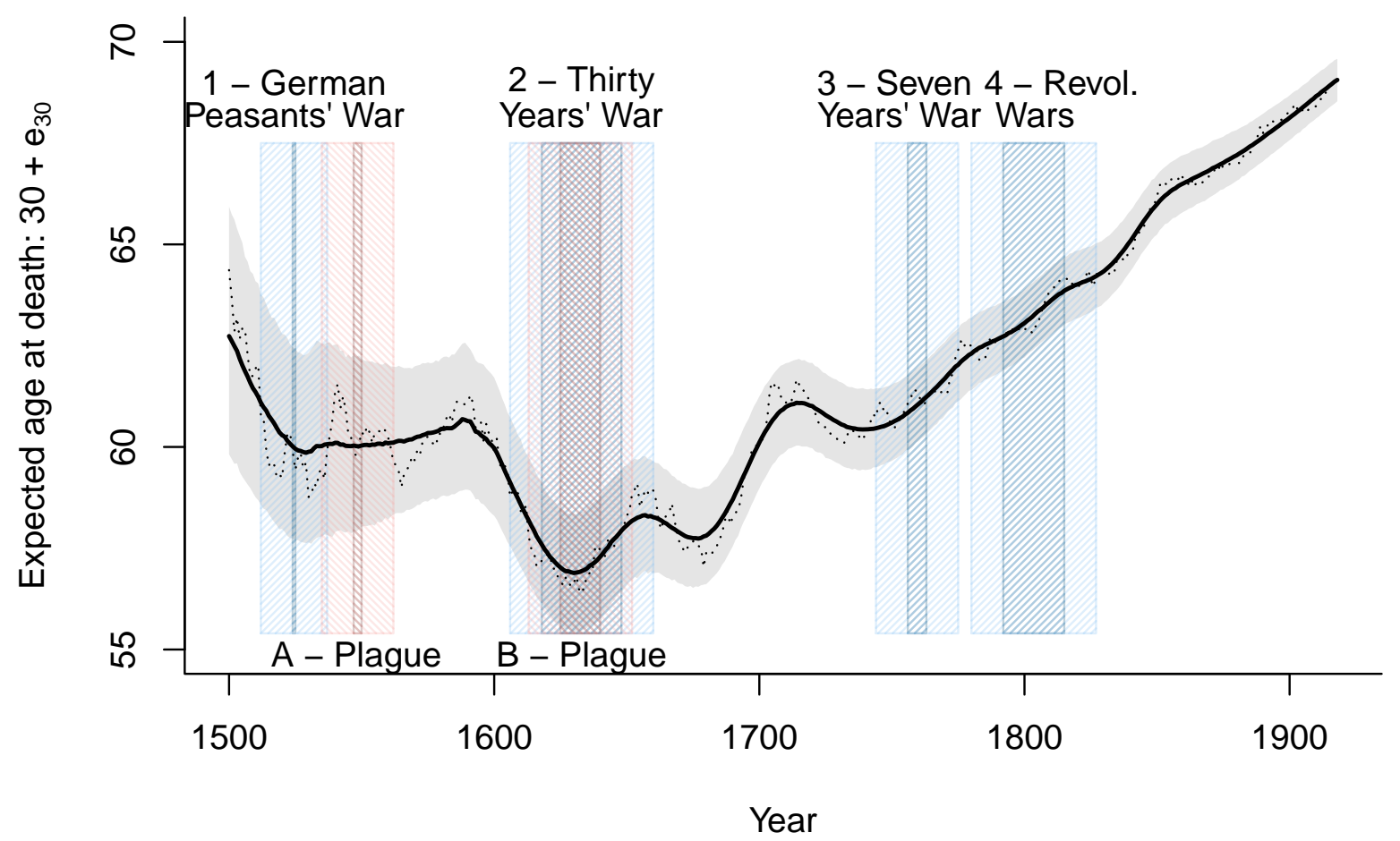

Fig. 4. The dynamics of scholars' period life expectancy and historical events

Figure 4 applies 25-year rolling intervals and two-dimensional smoothed data. The solid black line displays our estimated period life expectancy for scholars at age 30 in 25-year rolling intervals. For instance, the year 1550 covers the $1538-1562$ period. The gray area marks the corresponding $95 \%$ confidence intervals. The brighter surrounding years on the left and the right of each event indicate estimated life expectancies that include years altered by the events due to the rolling intervals.

To shed light on life expectancy dynamics, we added to Fig. 4 two types of historical events that might have influenced life expectancy: wars and pandemics. We identified four military conflicts that may have affected mortality dynamics: the German Peasants' War (1), the Thirty Years' War (2), the Seven Years' War (3), and the Revolutionary Wars (4). In addition, we identified two waves of the plague (years 1547-1550 and 1625-1640) that may have influenced mortality dynamics. 
In the 1500-1600 period, our point estimates for life expectancy at age 30 fluctuate strongly around the smoothed average of approximately 30 years. This period includes two important historical events that may have reduced life expectancy: the German Peasants' War and the plague pandemic. While it is possible that these events influenced the scholars' life expectancy, the small-sample variation and the width of the confidence intervals until around 1600 are so large that we cannot draw clear conclusions.

The strongest association between life expectancy and the historical events was in the early part of the seventeenth century, where we observe a sharp decline in life expectancy coinciding with both the Thirty Years' War (1618-1648) and the second plague pandemic. It is plausible that the mortality crisis was caused by one or both of these historical events. For the Thirty Years' War in particular, mediating effects may have been more important than the direct effects of military conflicts. Greifswald, for instance, was forced to billet more than a thousand Imperial soldiers - along with their horses and armaments - after the Duke of Pomerania surrendered in 1627. During this period, university life was limited, and professors did not receive salaries (Langer, 2011). The passing soldiers spread infectious diseases, while hygienic standards deteriorated. The seemingly endless string of plague epidemics that occurred between 1625 and 1640 (surface B in Fig. 4) illustrate the harsh conditions surrounding the Thirty Years' War, and may explain the very high death rates. During the war, people suffered not only from the plague, but from famine (Alfani and Gráda, 2018). Hence, it is likely that the three famous Malthusian mechanisms - famine, epidemics, and war - combined to lower life expectancy (Flinn, 1981).

At the end of the Thirty Years' War, life expectancy started to recover and death rates decreased, albeit with some fluctuations in the first part of the eighteenth century. Still, it took almost a century for life expectancy to return to pre-war and pre-plague levels. It should be noted that this period of declining mortality could be misinterpreted as signaling the onset of systematic mortality improvements if the time span does not include the pre-crisis period.

Figure 4 shows that systematic mortality improvements that cannot be interpreted as recovery from a crisis started around 1750. From that point onward, life expectancy increased without interruptions. Thus, no clear association between subsequent wars and life expectancy is observable. 


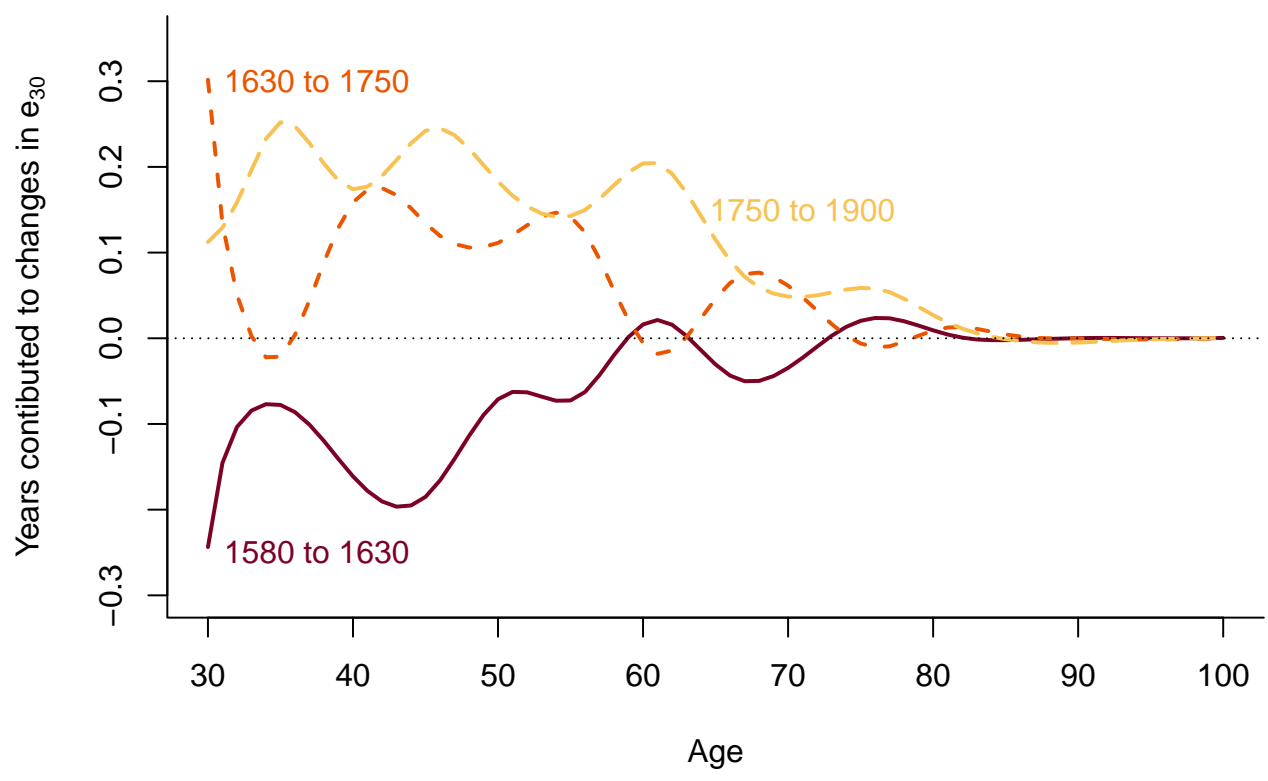

(a) Contribution to decline (1580 to 1630), recovery (1630 to 1750), and increase (1750 to 1900) in life expectancy by age

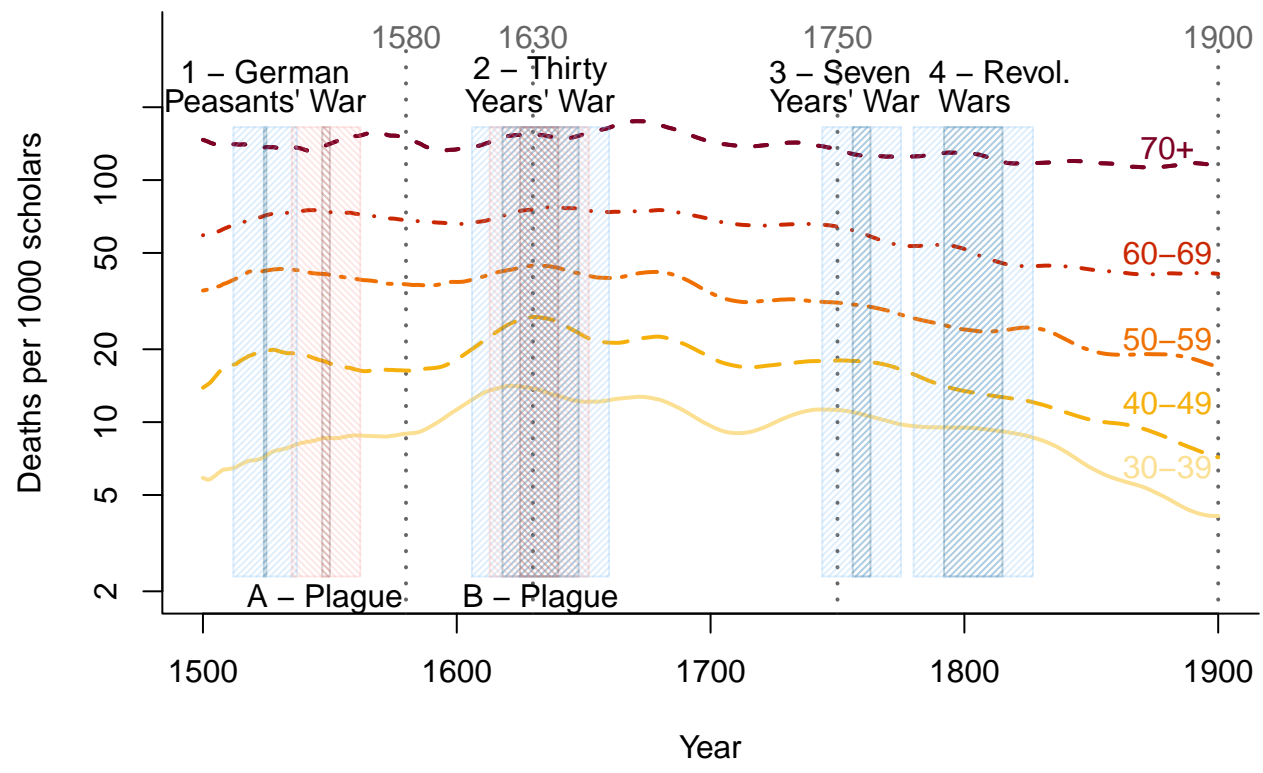

(b) Age-specific death rates

Fig. 5. Decomposition of gains in life expectancy.

Figure 5 applies 25-year rolling intervals and two-dimensional smoothed data. 
Figure 5a shows which ages contributed to the life expectancy changes across the three stages we identified: decline from 1580 to 1630; recovery from 1630 to 1750; and increase from 1750 to 1900. Figure 5b shows age-specific mortality trends over the whole time period. In the first stage, not all ages were equally affected by declining life expectancy. Almost all of the life expectancy losses were among people under age 60 (Fig. 5a). Older people (ages 60-69 and 70+) also experienced mortality increases during this period (Fig. 5b), but their contributions to life expectancy losses were small because so few individuals survived to these advanced ages. The decomposition also shows that people under age 60 were the main contributors to life expectancy gains in the late seventeenth and early eighteenth centuries: i.e., the increase in life expectancy was effectively driven by the same ages that drove the seventeenth-century mortality crisis. When the secular increase in longevity started in the mid-eighteenth century, people aged 60-80 joined people under age 60 in contributing to life expectancy increases (Fig. 5a). Figure 5b shows that after 1750, mortality declined fastest in the older age groups.

\subsection{Comparison to Other Studies}

We have presented our results by period to facilitate the analysis of when mortality improvements started. Many other studies have used the cohort perspective. For comparative purposes, we convert our data to the cohort perspective. The message of our cohort results is similar to that of our findings from the period perspective: i.e., cohort life expectancy did not improve between the 1400 and 1700 birth cohorts; life expectancy declined for the cohorts born in the late sixteenth century who were adults during the Thirty Years' War and the second plague pandemic; and secular improvements in life expectancy began with the cohorts born in the eighteenth century. Figure 6 compares our cohort life expectancy estimates at age 30 to others found in the literature.

We compare our results to five other sets of findings pertaining to nobles between 1400-1800 in North and Northeastern Europe as well as Central and Eastern Europe (Cummins, 2017); famous people between 1400-1875 (de la Croix and Licandro, 2015); cardinals in 1400-1900

(Fornasin et al., 2010); and Swedish life expectancy in 1751-1899 (from the Human mortality database (HMD), 2019).

We highlight two different dimensions of this comparison: trends and levels. The trends show qualitative similarities: nobles (Cummins, 2017), famous people (de la Croix and Licandro, 2015), and scholars of the HRE (this manuscript) all experienced periods of stagnation in mortality followed by sustained increases in life expectancy. However, the mortality im- 
provements started earlier among famous people (1680s) and later among Sweden's male birth cohorts (1800) and cardinals (1850s) than among scholars and nobles. More importantly, none of the other populations underwent the mortality crises observed among cohorts born at the end of the sixteenth century. Due to the differences in territorial coverage, the impact of the Thirty Years' War is likely less important in this comparison.

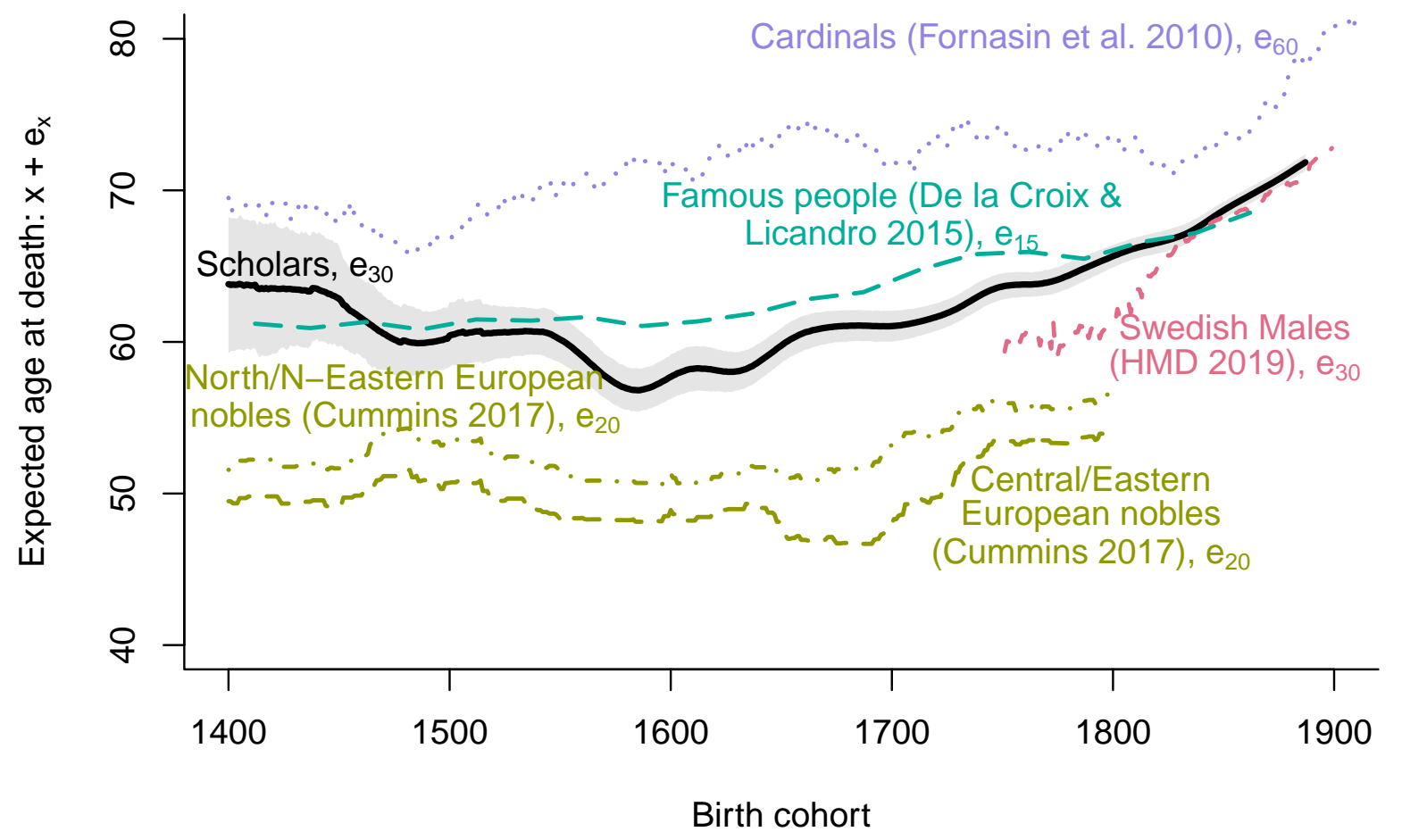

Fig. 6. The dynamics of scholars' cohort life expectancy in light of the literature Figure 6 applies 25-year rolling intervals and two-dimensional smoothed data of scholars.

However, the studies report very different levels of life expectancy, primarily because they use different starting ages: Cummins (2017) uses age 20 and Fornasin et al. (2010) use age 60; while de la Croix and Licandro (2015) exclude famous individuals who died before age 15. Only the Swedish life expectancy from the HMD is based on a starting age of 30. These different starting ages lead to predictable differences in levels. It is, for example, worth considering what difference it makes that Cummins uses age 20, and therefore includes a larger share of young adult mortality. In the HMD life tables for Sweden, mean age at death conditional to surviving to age 20 for the 1800 male cohort is 56.1, and 59.2 conditional 
on surviving to age 30. The differences between our 1800 cohort and Cummins' nobles are 9.2 years in North and Northeastern Europe and 11.5 years in Central and Eastern Europe. Hence, these differences are larger than the 3.1 years in the HMD for Swedish cohorts. The remaining life expectancy discrepancies between scholars and nobles can be explained by the high shares of violent deaths among nobles (Cummins, 2017). The life expectancy gap between scholars and cardinals is 7.9 years in 1800, and is thus smaller than the difference based on the calculation from HMD's life tables for Swedish males (12 years). Finally, we do not observe any noteworthy systematic deviation from the unconditional mean age at death estimated by de la Croix and Licandro (2015) for famous people who survived until age 15.

\subsection{Life Expectancy, Social Status, and Medical Knowledge}

Figure 7 illustrates the mortality dynamics of scholars separated into four groups according to their field of science and membership in an academy of sciences. The figure starts in 1600 for university scholars and in 1700 for academy members, because these stratified samples would be too small for the earlier years. Panel A compares university professors who were and were not in the field of medicine. We observe no systematic mortality difference between these groups of scholars until the early to mid-eighteenth century, when life expectancy started to increase among scholars not in medicine. Mortality improvements among scholars linked to the medical field were delayed. In line with van Poppel et al. (2016), we find that life expectancy was lower for scholars in medicine than for other scholars for around one hundred years. However, this mortality gap decreased toward the end of the nineteenth century.

Panel B compares mortality improvements among scholars who were and were not in medicine, and who were active in academies of sciences. The pattern is similar to that observed among university scholars: starting from around 1750, scholars who were not in medicine experienced mortality declines; while those who were in medicine experienced these declines with a delay; with the gap narrowing toward the end of the nineteenth century.

Panels $\mathrm{C}$ and D compare university scholars to those nominated to a scientific academy. Panel C refers to scholars outside medicine, while Panel D refers to scholars in medicine. Both panels show that around 1750, members of the academies had a higher life expectancy.

This mortality advantage lasted for approximately 100 years, until 1850. Thereafter the differences fluctuated so strongly that we refrain from drawing conclusions other than that the advantage existed approximately from 1750 to 1850; and then perhaps diminished. 


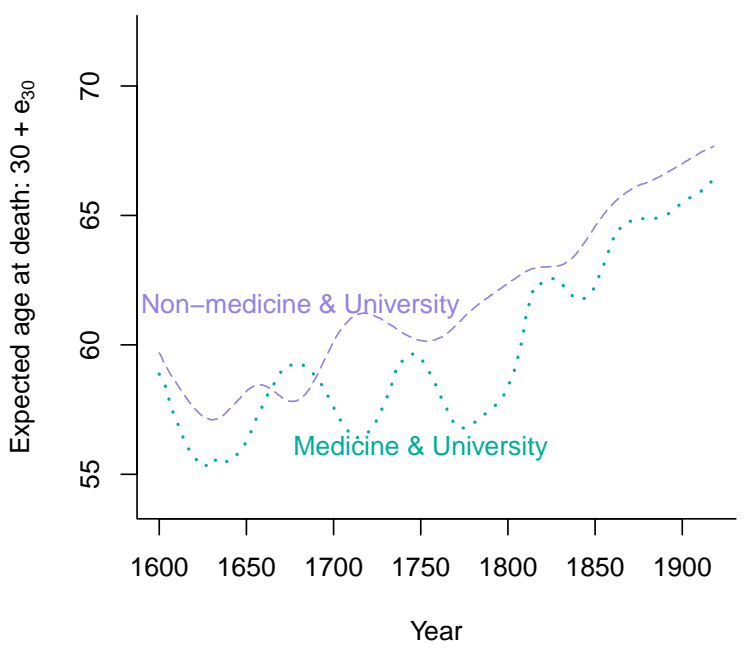

(a) Medicine and Non-medicine in Universities

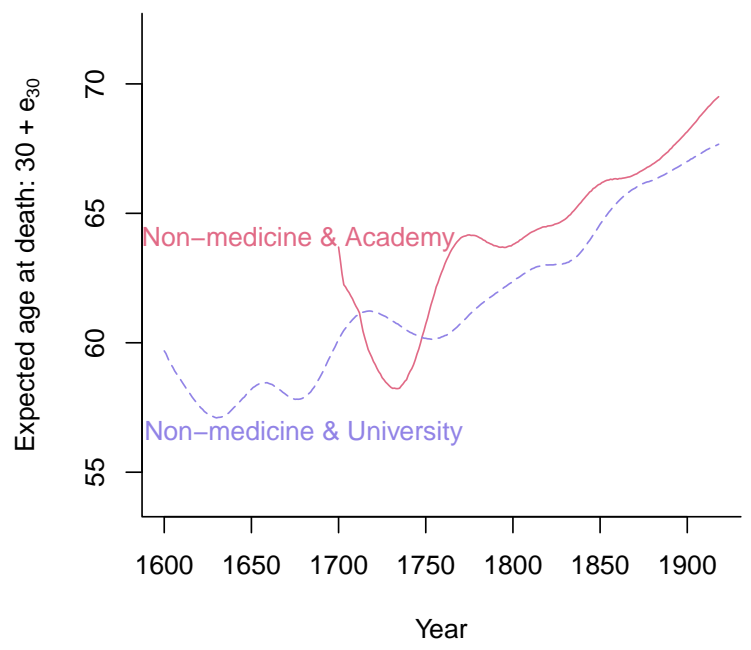

(c) Non-medicine in Universities and Academies

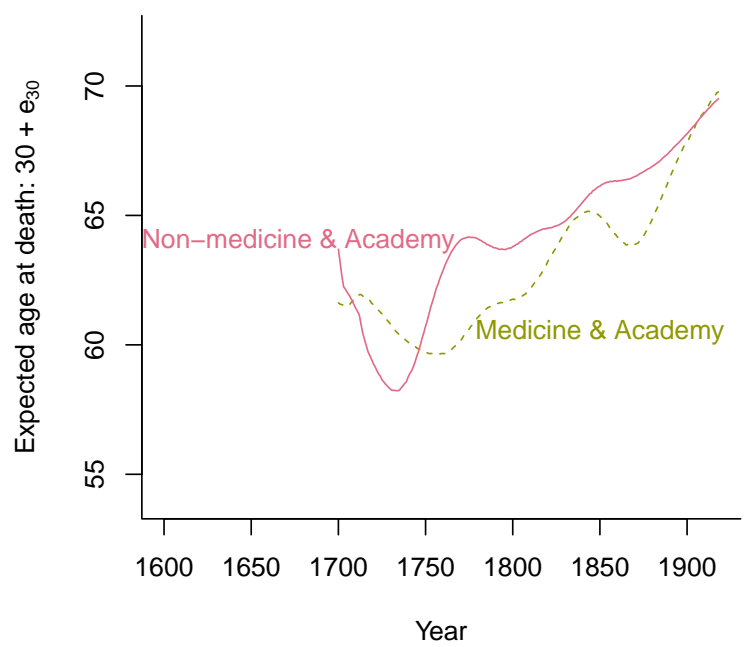

(b) Medicine and Non-Medicine in Academies

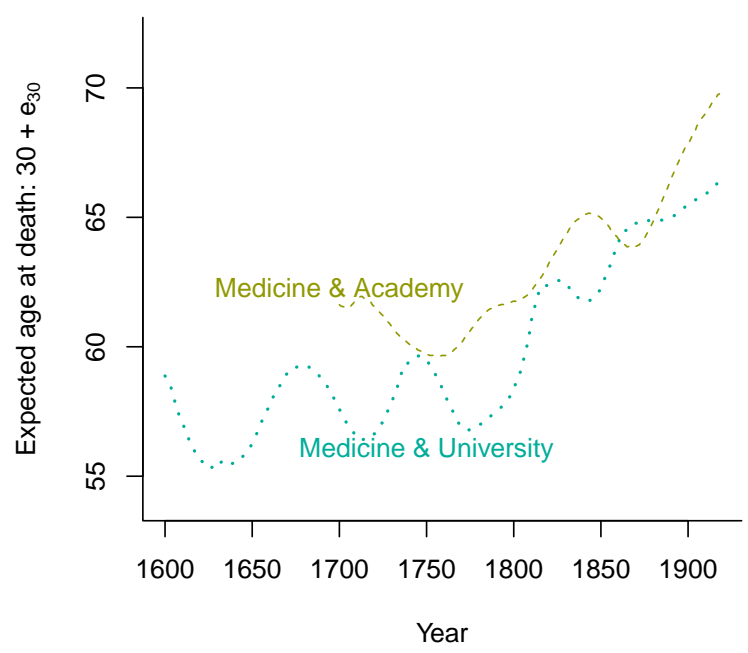

(d) Medicine in Universities and Academies

\section{Fig. 7. Social status, medicine, and life expectancy}

Figure 7 applies 25-year rolling intervals and two-dimensional smoothed data. 


\subsection{Robustness}

We analyzed whether the following findings remained after data limitations: life expectancy stagnated from 1500 to 1600; the early seventeenth century was marked by a mortality crisis; secular increases started around 1750; and scholars who were outside medicine and belonged to academies of science had a mortality advantage compared to scholars who were in medicine and were not appointed to academies.

We first limited the sample to data from institutions for which we had (almost) complete data or partially complete data; these correspond to categories 1 and 2 in the classification presented in the data section. It also excludes institutions without traditional sources such as books. Second, to test the robustness with respect to birth and death year heaping, we excluded all observations with a year of birth ending on zero or five. Third, we estimated life expectancy with varying starting ages: $25,35,45$, and 55. Our key results were robust to these tests (see Fig. A7-A10 in the supplementary material).

\section{Discussion}

We gathered data from thousands of scholars in the 1648 territories of the Holy Roman Empire and the Netherlands. By combining vital information with appointment and exit information, we were able to compute mortality dynamics, while taking into account left truncation and right censoring. Based on this novel dataset, we provide new insights into when mortality first started to decline, and which groups were the first to experience rising longevity. Our results show that adult life expectancy was stagnant from 1500 to 1750; the early seventeenth century was marked by a mortality crisis; secular increases started around 1750; and scholars outside medicine and within academies of science had a mortality advantage compared to those within medicine and not appointed to academies. These results partially corroborate and partially challenge prior findings. Furthermore, they persisted after several robustness checks were performed.

The heterogeneity in our population of scholars enabled us to study differentials in the timing of mortality improvements. We showed that the higher social status of members of scientific academies relative to that of ordinary scholars at universities was associated with earlier improvements in mortality. These findings are in line with the vast literature showing that social status and life expectancy are positively correlated (Johansson, 1999; Elo et al., 2014; Andreev et al., 2011). Importantly, we show that this difference already existed in the eighteenth century. However, our results suggest that this difference may have 
been temporarily and diminished towards the end of the nineteenth century. It is possible that during this period, the comparatively elevated social status associated with being a member in a scientific academy, rather than an "ordinary" professor, might have weakened. Universities changed from being vocational schools to being research institutions following the Humboldt reform (Schimank and Winnes, 2000).

We also found that mortality improvements were delayed among medical professionals. The lack of understanding of germ theory before the nineteenth century suggests that scholars in the medical field would have faced a mortality disadvantage. However, we found no systematic disadvantage among medical professionals until the beginning of the secular longevity improvements. The limited role of formal medicine in healing is a possible explanation for this finding. While having an academic career was certainly useful for obtaining official positions, like court or personal physician, and was, therefore, linked to social status; it was not necessarily an advantage in competing with practitioners on the medical marketplace, like surgeons, midwives, barbers, apothecaries, and even folk healers and illegal care providers (Broman, 1995). It is even possible that the high social status of academic medical professionals gave them a mortality advantage. However, when systematic mortality improvements began and the role of formal medicine increased, the gains for medical professionals were delayed. In line with van Poppel et al. (2016), we found that medical professionals had a mortality disadvantage for almost a century. Rapidly increasing medical knowledge and the diffusion of germ theory might have quickly compensated for the higher infection risks. As early as in the nineteenth century, excess mortality declined among scholars in the medical profession, regardless of whether they belonged to academies of science.

Our estimation of scholars' longevity also provides us with insights into the capacity for knowledge accumulation and diffusion. Our finding that the rise in longevity among the educated segment of society preceded industrialization is consistent with the hypothesis that human capital played a significant role in the process of industrialization and the take-off to modern growth (Galor, 2011). The number of scholars and the length of their productive lives may have affected how much they were able to influence their cultural and economic environments - and, in turn, socioeconomic development and economic growth. ${ }^{9}$

The population of scholars we analyzed has the clear advantage of representing a distinct

\footnotetext{
${ }^{9}$ The outstanding role of upper-tail human capital in Europe's historical developments - and, more precisely, in its knowledge accumulation, economic growth, and industrialization - has been emphasized in the recent research literature. For example, the number of people in eighteenth-century France who subscribed to the Diderot's and d'Alembert's Grande Encyclopédie predicts subsequent economic development at both the city and the county level (Squicciarini and Voigtländer, 2015). Moreover, German cities that developed better institutions following the Reformation grew more quickly, and had more residents who were registered as famous in the German biography database (Dittmar and Meisenzahl, 2016).
} 
universe: i.e., individuals active at one of the defined institutions. However, our data selection also comes with limitations. First, our data referred almost exclusively to elite men (only 89 women were in the sample).

Second, as universities and academies of sciences are urban institutions, our population was also urban. Thus, these scholars were exposed to the urban mortality penalty (Vögele, 2000; Woods, 2003). As we were not able to analyze mortality among ordinary people or women, we can only speculate about the life expectancy dynamics in the general population during the era we analyzed. Our finding that the elite lost several years of life expectancy during the Thirty Years' War might suggest that the general population experienced a similar or greater mortality crisis, as it is a reasonable assumption that social status had a protective effect during wars and pandemics. The differences in the timing of secular mortality gains among the upper tail of the elite (members of the academies) and the normal elite (professors) may also suggest that in the general population, secular mortality improvements did not start before the middle or the end of the eighteenth century. However, this speculation may be wrong, as most scholars were living in urban areas. Thus, the levels and the timing of mortality improvements among scholars may have differed from those of ordinary people living in rural areas (Woods, 2003).

Third, the characteristics of the institutions and their members evolved over time. The structure of universities was quite different in the late medieval era than it was in more recent periods. ${ }^{10}$ Prior to the modern era, scholars' salaries were often paid in kind (or not all). Thus, while working at a university was linked to higher social status, it often did not generate significant income advantages. Furthermore, the process of appointment - and, hence, of selection into our population - changed. The role of kinship in the appointment process was gradually replaced by scientific criteria (Vandermeersch, 2003; Klinge, 2004).

Fourth, how we defined scholars and which institutions we included are potential drivers of the estimated population size. For instance, we may have underestimated the growth in the scholar population in the nineteenth century, as we did not include universities founded later than the eighteenth century. It is also possible that scholars were active in a scientific institution before the first observed appointment. If so, we lose years at risk at earlier ages, and our life expectancy estimates are biased downwards. The academic position that defines the entry in the dataset also varies across sources.

Fifth, since the scholars were not appointed until they reached young adulthood, our investigation is limited to adult mortality. The effects of shifts in infant and child mortality on

\footnotetext{
${ }^{10} \mathrm{We}$ summarize some major evolutions in the characteristics of the universities and their scholars in the supplementary material.
} 
the evolution of life expectancy are neglected.

Finally, our new dataset does not allow us to draw conclusions about the impact of social status or the medical profession on mortality. We can only identify associations.

In summary, our analysis of a new dataset covering more than 30,000 scholars provides new information on when mortality first started to decline, and on the social differentials in the first mortality gains. We find that adult mortality was stagnant or declining from the sixteenth to the seventeenth century, as wars and epidemics led to a mortality crisis that resulted in the loss of several years of adult life expectancy. However, secular life expectancy improvements started as early as in the eighteenth century, and the life expectancy of scholars associated with elite academies (rather than only being affiliated with a university) increased first, while mortality improvements were delayed for scholars in medicine. Our results provide a new perspective on the historical timing of mortality improvements, and on the socioeconomic and occupational differentials in this timing. A database accompanying our paper facilitates replication and extensions. 


\section{Acknowledgments}

The data collection greatly benefited from all the universities that were willing to share their professor catalogues with us: the University of Amsterdam (album acaemicum), the University of Groningen (catalogus professorum academeiae groninganae), Leiden University (leidse hoogleraren vanaf 1575), the University of Leipzig (catalogus professorum lipsiensis), the University of Marburg (catalogus professorum academiae marburgensis), the University of Rostock (catalogus professorum rostochiensium) and the University of Utrecht (catalogus professorum academiae rheno-traiectinae). We also gratefully acknowledge the data on members provided by the following academies of science: the Academy of Sciences and Literature in Mainz, the Bavarian Academy of Sciences and Humanities, the Berlin-Brandenburg Academy of Sciences and Humanities, the Heidelberg Academy of Sciences and Humanities, the Leopoldina, and the Saxon Academy of Sciences. Furthermore, we are thankful to Dagma Drüll and Tino Fröde for sharing with us additional material and their knowledge in supplements to their published works on the University of Heidelberg and the Upper Lusatian Academy of Sciences, respectively; to Tino Steyer for providing the data on the University of Helmstedt; to the members of the working group on the Kiel professors for sharing their work in progress, to the Göttingen Academy of Sciences and Humanities and the Royal Netherlands Academy of Arts and Sciences for sending us books with the available data; and to all others who provided us with valuable information and input in the process of data collection. Finally, we thank Julie Duchêne and Guillaume Catoire for their help in building the database for Louvain, and we are deeply grateful for the patient support of Annika Onemichl in the process of gathering and cleaning the data.

The paper benefited from the advises we received and the discussions we took part in at the Max Planck Institute of Demographic Research as well as from the comment of participants at the work shop "Elite human capital and the road to modernity: The East vs the West" in Marseilles 2017. David de la Croix acknowledges the financial support of the project ARC 15/19-063 of the Belgian French-speaking Community. He also thanks Imera (Marseille, France) for welcoming him during fall 2017, and for funding Robert Stelter's visit there.

Data and codes are available on OSF. 


\section{References}

Alfani, G. and Gráda, C. Ó. (2018). The timing and causes of famines in Europe. Nature Sustainability, 1 (6), 283-288.

Andreev, E. M., Jdanov, D., Shkolnikov, V. M. and Leon, D. A. (2011). Longterm trends in the longevity of scientific elites: Evidence from the British and the Russian academies of science. Population Studies, 65 (3), 319-334.

- and Shkolnikov, V. M. (2010). Spreadsheet for calculation of confidence limits for any life table or healthy-life table quantity. Max Planck Institute for Demographic Research (MPIDR Technical Report), 5.

- and - (2012). An Excel spreadsheet for the decomposition of a difference between two values of an aggregate demographic measure by stepwise replacement running from young to old ages. Max Planck Institute for Demographic Research (MPIDR Technical Report TR-2012-002).

- - — and Begun, A. Z. (2002). Algorithm for decomposition of differences between aggregate demographic measures and its application to life expectancies, healthy life expectancies, parity-progression ratios and total fertility rates. Demographic Research, 7, $499-522$.

Bengtsson, T. and Dribe, M. (2011). The late emergence of socioeconomic mortality differentials: A micro-level study of adult mortality in southern Sweden 1815-1968. Explorations in Economic History, 48 (3), 389-400.

- and van Poppel, F. (2011). Socioeconomic inequalities in death from past to present: An introduction. Explorations in economic History, 48 (3), 343-356.

Broman, T. (1995). Rethinking professionalization: Theory, practice, and professional ideology in eighteenth-century German medicine. The Journal of Modern History, 67 (4), 835-872.

Camarda, C. G. et al. (2012). MortalitySmooth: An R package for smoothing Poisson counts with P-splines. Journal of Statistical Software, 50 (1), 1-24.

Carrieri, M. P. and Serraino, D. (2005). Longevity of popes and artists between the 13th and the 19th century. International Journal of Epidemiology, 34 (6), 1435-1436. 
Charle, C. (2004). Patterns. In W. Rüegg (ed.), A History of the University in Europe: Universities in the nineteenth and early twentieth centuries (1800-1945), vol. 3, Cambridge: Cambridge University Press, pp. 33-82.

ChiAng, C. L. (1984). The life table and its applications. Robert E. Krieger Publishing.

Conrad, E. (1960). Die Lehrstühle der Universität Tübingen und ihre Inhaber (1477-1927). Tübingen.

Cummins, N. (2017). Lifespans of the European Elite, 800-1800. The Journal of Economic History, 77 (2), 406-439.

DE LA Croix, D. (2017). Did Longer Lives Buy Economic Growth? From Malthus to Lucas and Ben-Porath. In M. Cervellati and U. Sunde (eds.), Demographic Change and Long-Run Development, MIT Press, pp. 69-89.

— and Licandro, O. (2015). The Longevity of Famous People from Hammurabi to Einstein. Journal of Economic Growth, 20, 263-303.

— and Sommacal, A. (2009). A Theory of Medical Effectiveness, Differential Mortality, Income Inequality and Growth for Pre-Industrial England. Mathematical Population Studies, $16(1), 2-35$.

Deutsche Biographie (2014-). Bayerische Akademie der Wissenschaften Historische Kommission, Bayerische Staatsbibliothek, https://www.deutsche-biographie.de [online source].

Dittmar, J. and Meisenzahl, R. R. (2016). State Capacity and Public Goods: Institutional change, Human Capital and Growth in Early Modern Germany. CEP Discussion Papers dp1418, Centre for Economic Performance, LSE.

Drüll, D. (2009). Heidelberger Gelehrtenlexikon 1933-1986. Berlin, Heidelberg: Springer.

DrülL, D. (2012). Heidelberger Gelehrtenlexikon 1803-1932. Berlin, Heidelberg: Springer.

Drüll-Zimmermann, D. (1991). Heidelberger Gelehrtenlexikon 1652-1802. Berlin, Heidelberg: Springer.

Drüll-Zimmermann, D. (2002). Heidelberger Gelehrtenlexikon 1386-1651. Berlin, Heidelberg: Springer.

EDwards, R. D. (2008). Declining mortality among British scientists during the Age of Enlightenment. Population and Development Review, 34, 103-125. 
Elo, I. T., Martikainen, P. and Myrskylä, M. (2014). Socioeconomic status across the life course and all-cause and cause-specific mortality in Finland. Social Science 85 Medicine, 119, 198-206.

Fischer, K. F. A. (1978). Jesuiten-Mathematiker in der deutschen Assistenz bis 1773. Archivum Historicum Societatis Iesu, 47, 159-224.

Flessa, D. (1969). Die Professoren der Medizin zu Altdorf von 1580 - 1809. Universität Erlangen-Nürnberg.

FlinN, M. W. (1981). The European demographic system 1500-1820. In Johns Hopkins Symposia in Comparative History, 12, Johns Hopkins University Press Baltimore Md. United States 1981.

Fornasin, A., Breschi, M. and Manfredini, M. (2010). Mortality patterns of cardinals (sixteenth-twentieth centuries). Population, 65 (4), 631-652.

Frijhoff, W. (1996). Patterns. In W. Rüegg (ed.), A History of the University in Europe: Universities in the Early Modern Europe (1500-1800), vol. 2, Cambridge: Cambridge University Press, pp. 43-113.

Galor, O. (2011). Unified growth theory. Princeton University Press.

GüNther, J. (1858). Lebensskizzen der Professoren der Universität Jena seit 1558 bis 1858: Eine Festgabe zur 300-jährigen Säkularfeier der Universität am 15., 16., und 17. August 1858. Jena: Mauke.

Hanley, J. A., Carrieri, M. P. and Serraino, D. (2006). Statistical fallibility and the longevity of popes: William Farr meets Wilhelm Lexis. International Journal of Epidemiology, 35 (3), 802-805.

HobBs, F. (2004). Age and sex composition. In H. S. Shryock, J. S. Siegel and E. A. Larmon (eds.), The methods and materials of demography, 2nd edn., US Bureau of the Census, pp. $125-174$.

Hollingsworth, T. (1977). Mortality in the British peerage families since 1600. Population, 32, 323-352.

Human mortality database (2019). University of California, Berkeley (USA), and Max Planck Institute for Demographic Research (Germany),. Available at www.mortality.org or www.humanmortality.de (data downloaded on 01.12.2019). 
Johansson, S. R. (1999). Death and the doctors: medicine and elite mortality in Britain from 1500 to 1800. Cambridge Group for the History of Population and Social Structure.

Klinge, M. (2004). Teachers. In W. Rüegg (ed.), A History of the University in Europe: Universities in the Nineteenth and Early Twentieth Centuries 1800-1945, vol. 3, 5, Cambridge University Press, pp. 123-162.

LAnger, H. (2011). Die Universität Greifswald im Dreißigjährigen Krieg. In T. Kossert (ed.), Universitäten im Dreißigjährigen Krieg, Potsdam: Univ. Verlag.

LucAs, R. E., JR. (2009). Ideas and Growth. Economica, 76 (301), 1-19.

Pfister, U. and Fertig, G. (2010). The population history of Germany: research strategy and preliminary results. MPIDR working paper, 2010-035.

Schimank, U. and Winnes, M. (2000). Beyond Humboldt? The relationship between teaching and research in European university systems. Science and Public Policy, 27 (6), $397-408$.

Schumacher, R. and OrIs, M. (2011). Long-term changes in social mortality differentials, Geneva, 1625-2004. Explorations in Economic History, 48 (3), 357-365.

Squicciarini, M. P. and Voigtländer, N. (2015). Human Capital and Industrialization: Evidence from the Age of Enlightenment. The Quarterly Journal of Economics, 130 (4), $1825-1883$.

SteIGer, G. (1981). Magister und Scholaren, Professoren und Studenten: Geschichte deutscher Universitäten und Hochschulen im Überblick. Leipzig: Urania-Verlag.

VAN DE KAA, D. J. and DE Roo, Y. (2007). The members of the Royal Netherlands Academy of Arts and Sciences: 1808 to 2000. A demographic view. Netherlands Interdisciplinary Demographic Institute, Working paper, 2007/2.

van Poppel, F., Bijwahrd, G., van Lieburg, M., van Lieburg, F., Hoekstra, R. and Verkade, F. (2016). The Life Expectancy of Medical Professionals in the Netherlands, Sixteenth to Twentieth Centuries. Population, 71 (4), 619-640.

-, VAN DE KAA, D. J. and BiJwaARD, G. E. (2013). Life expectancy of artists in the Low Countries from the fifteenth to the twentieth century. Population Studies, 67 (3), $275-292$. 
VAndenbroucke, J. (1985). Survival and expectation of life from the 1400's to the present A study of the knighthood order of the Golden Fleece. American Journal of Epidemiology, 22 (6), 1007-1015.

Vandermeersch, P. A. (2003). Teachers. In H. De Ridder-Symoens (ed.), A History of the University in Europe: Universities in Early Modern Europe 1500-1800, vol. II, 5, Cambridge University Press, pp. 210-255.

VöGELE, J. (2000). Urbanization and the urban mortality change in Imperial Germany. Health \& Place, 6 (1), 41-55.

Winkler-Dworak, M. (2008). The low mortality of a learned society. European Journal of Population/Revue européenne de Démographie, 24 (4), 405-424.

Woods, R. (2003). Urban-rural mortality differentials: an unresolved debate. Population and Development Review, 29 (1), 29-46. 


\section{A Supplementary Material}

Leaders and Laggards in Life Expectancy among European Scholars from the Sixteenth to the Early Twentieth Century

Robert Stelter, David de la Croix and Mikko Myrskylä 


\section{A.1 Universities and Academies of Sciences}

Tab. A1: Sources for Universities and Academies of Sciences

\begin{tabular}{|c|c|c|c|c|c|c|c|}
\hline No. & University & Year & Cat. & Obs. & Wiki & RAG & Sources \\
\hline \multicolumn{8}{|c|}{ Universities in the Holy Roman Empire 1348-1599 } \\
\hline 1. & University of Prague & 1348 & 2 & 1315 & $\mathrm{x}$ & $\mathrm{x}$ & $\begin{array}{l}\text { Čornejová and Fechtnerová (1986); } \\
\text { Svatoš (1995) }\end{array}$ \\
\hline 2. & University of Vienna & 1365 & 2 & 1508 & $\mathrm{x}$ & $\mathrm{x}$ & Lackner (1976) \\
\hline 3. & University of Heidelberg & 1386 & 1 & 1995 & & & Drüll (1991; 2002; 2009; 2012) \\
\hline 4. & University of Cologne & 1388 & 2 & 722 & $\mathrm{x}$ & $\mathrm{x}$ & Bianco (1974) \\
\hline 5. & University of Erfurt & 1389 & 3 & 309 & $\mathrm{x}$ & $\mathrm{x}$ & \\
\hline 6. & University of Würzburg & 1402 & 2 & 761 & & & Walter (2010); Reindl (1966) \\
\hline 7. & Leipzig University & 1409 & 1 & 1184 & & & Catal. Prof. Lipsiensium \\
\hline 8. & University of Rostock & 1419 & 1 & 809 & & & Catal. Prof. Rostochiensium \\
\hline 9. & University of Dole & 1422 & 3 & 63 & & & Fourquet (1929) \\
\hline 10. & University of Louvain & 1425 & 2 & 680 & & & $\begin{array}{l}\text { Brants (1906); Nève (1856); } \\
\text { Ram (1861); Lamberts and Roegiers (1990); } \\
\text { Tricot-Royer (1927) }\end{array}$ \\
\hline 11. & University of Greifswald & 1456 & 3 & 725 & $\mathrm{x}$ & & \\
\hline 12. & University of Freiburg & 1457 & 2 & 696 & $\mathrm{x}$ & & $\begin{array}{l}\text { Bauer (1957); Ruth (2001); } \\
\text { Kurrus (1977) }\end{array}$ \\
\hline 13. & University of Ingolstadt & 1472 & 3 & 236 & & & \\
\hline 14. & University of Trier & 1473 & 4 & 69 & & & \\
\hline 15 . & University of Tübingen & 1477 & 1 & 993 & & & Conrad (1960) \\
\hline 16. & University of Mainz & 1477 & 1 & 974 & & & Benzing (1986) \\
\hline 17. & University of Wittenberg & 1502 & 2 & 169 & & & Kohnle and Kusche (2016) \\
\hline 18. & Brand. Uni. of Frankfurt & 1506 & 3 & 135 & $\mathrm{x}$ & & \\
\hline 19. & University of Marburg & 1527 & 1 & 1634 & & & $\begin{array}{l}\text { Marburger Prof.-katalog } \\
\text { Auerbach and Gundlach (1979); } \\
\text { Gundlach and Auerbach (1927) }\end{array}$ \\
\hline 20. & University of Strasbourg & 1538 & 2 & 531 & & & Berger-Levrault (1890) \\
\hline 21. & University of Dillingen & 1553 & 3 & 137 & $\mathrm{x}$ & & \\
\hline 22. & University of Jena & 1558 & 2 & 625 & & & Günther (1858) \\
\hline 23. & University of Douai & 1559 & 3 & 63 & & & \\
\hline 24. & University of Eichstätt & 1564 & 4 & 13 & & & \\
\hline 25 . & University of Olomouc & 1573 & 3 & 303 & $\mathrm{x}$ & & \\
\hline 26. & University of Linz & 1574 & 4 & 14 & & & \\
\hline 28. & University of Helmstedt & 1576 & 1 & 294 & & & Prof.-katalog Helmstedt \\
\hline 29. & University of Herborn & 1584 & 4 & 12 & & & \\
\hline 30. & University of Graz & 1585 & 2 & 531 & $\mathrm{x}$ & & Krones (1886) \\
\hline
\end{tabular}

Column Cat. contains the quality of data source: 1 almost complete data, 2 partially complete data, 3 non-complete data, and 4 scattered data. Column Obs. indicates the number of observations, and Wiki indicates whether at least some of the observations were found by means of Wikipedia. $R A G$ refers to data from the Repertorium Academicum Germanicum. Appendix A.5 provides an overview of the links to online professor catalogs that were included.

* Because of a joint source, the University of Strasbourg includes most of the observations. 


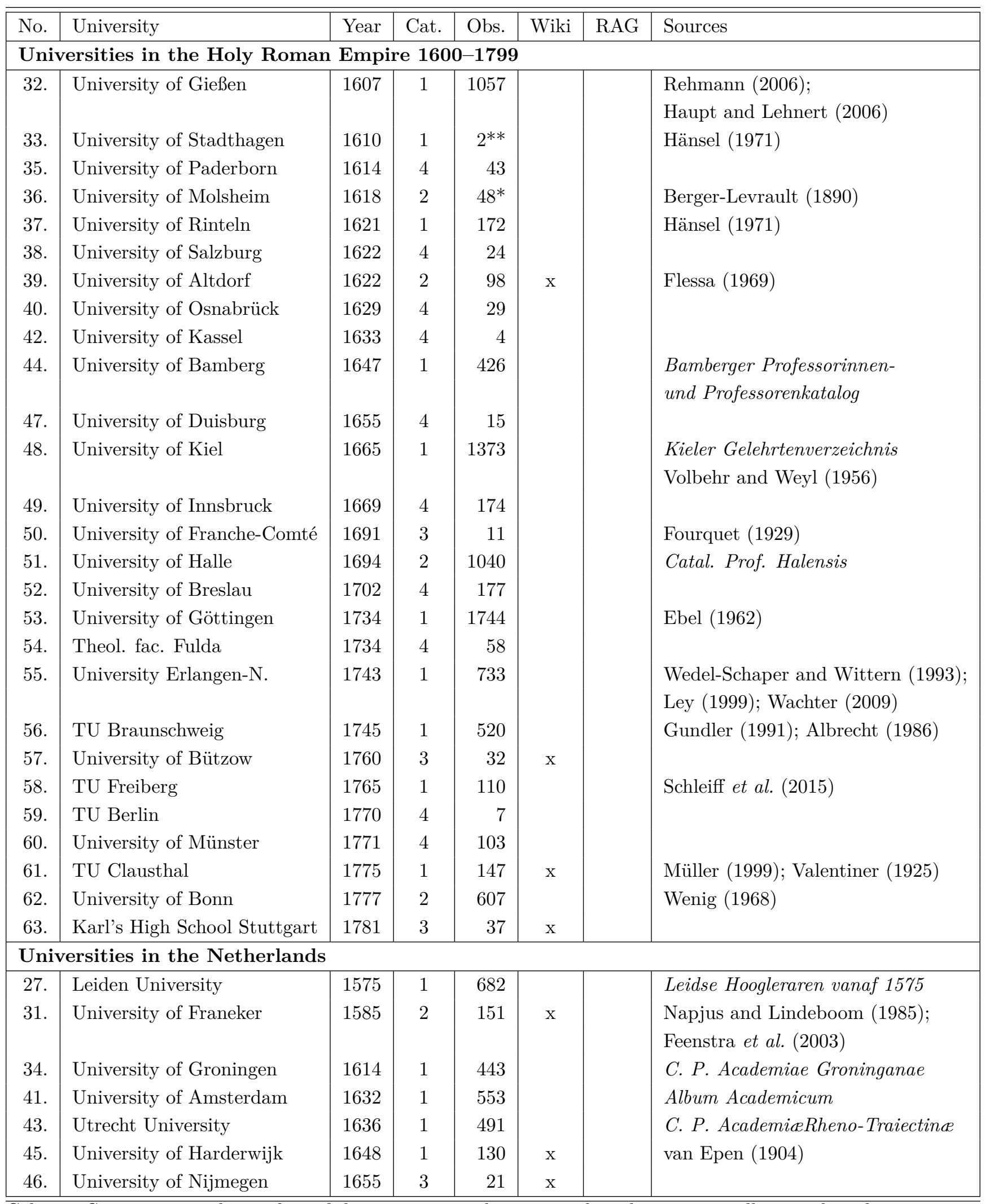

Column Cat. contains the quality of data source: 1 almost complete data, 2 partially complete data, 3 non-complete data, and 4 scattered data. Column Obs. indicates the number of observations, and Wiki indicates whether at least some of the observations were found by means of Wikipedia. $R A G$ refers to data from the Repertorium Academicum Germanicum. Appendix A.5 provides an overview of the links to online professor catalogs that were included.

** Because of a joint source, the University of Rinteln includes most of the observations. 


\begin{tabular}{|l|l|r|r|r|r|r|l|l|}
\hline \hline No. & Academy & Year & Cat. & Obs. & Wiki & Reg. & Sources \\
\hline \multicolumn{7}{|l|}{ Academies of sciences } \\
\hline 64. & Leopoldina & & 1652 & 1 & 4886 & & $\mathrm{x}$ & \\
65. & Berlin-Brandenburg & (BBAW) & 1700 & 1 & 2449 & & $\mathrm{x}$ & \\
66. & Göttingen & $($ AdW $)$ & 1751 & 1 & 1849 & & & Krahnke (2001) \\
67. & Erfurt & & 1752 & 1 & 1968 & & & Kiefer (2004) \\
68. & München & (BADW) & 1759 & 1 & 2568 & & $\mathrm{x}$ & \\
69. & Mannheim & & 1763 & 3 & 47 & $\mathrm{x}$ & & Eid (1926) \\
70. & Brussels & 1769 & 2 & 56 & & & Hasquin (2009) \\
71. & Görlitz & $($ OLGdW) & 1779 & 1 & 1985 & & & Fröde (2017) \\
72. & Amsterdam & (KNAW) & 1808 & 1 & 1602 & & & van de Kaa and Roo (2008) \\
73. & Leipzig & & 1846 & 1 & 448 & & $\mathrm{x}$ & \\
74. & Heidelberg & & 1909 & 1 & 310 & & $\mathrm{x}$ & \\
75. & Mainz & & 1949 & 1 & 175 & & $\mathrm{x}$ & \\
\hline \hline
\end{tabular}

Column Cat. contains the quality of data source: 1 almost complete data, 2 partially complete data, 3 noncomplete data, and 4 scattered data. Column Obs. indicates the number of observations, and Wiki indicates whether at least some of the observations were found by means of Wikipedia. Reg. refers to sources from official registers provided by the academy.

\section{A.2 Additional Material on the Data Quality}

The presentation of histograms (see Fig. A1-A4) and the shares of birth and death years ending on zero or five (see Fig. A5) are only two options for evaluating the quality of the data. The calculation of an adjusted Whipple-Index (Hobbs, 2004) is another option, and it also relates the birth or death years ending on zero or five to the overall number of births or deaths in the period. The index takes values between zero and 500. The index is 500 if all observations end with zero or five, and is 100 if the observations are uniformly distributed. Provided the index is lower than 105, heaping in the year of birth or death is considered low, and the data quality is considered high. Index values of 105-110 indicate that the data are relatively accurate, while index values of 110-125 suggest the data are fairly okay. The data quality can be considered poor at index values of $125-175$, and very poor at index values exceeding 175 .

Findings in Tab. A2 support the observations from Fig. 2. Already at the beginning of the sixteenth century, the quality of the birth year data is fairly okay. As soon as we only include observations with a year of birth that is not marked as "around", "approximated" and so on in the sources of our database, the data quality of early observations improves, and is already fairly okay in the second half of the sixteenth century. The adjusted Whipple-Index values on death year heaping show that the data quality is at least fairly okay already from the 
beginning of the fourteenth century in the overall sample. However, as soon as we limit the data to the observations from the baseline mortality estimation, the index does not exceed 125 fifty years later.

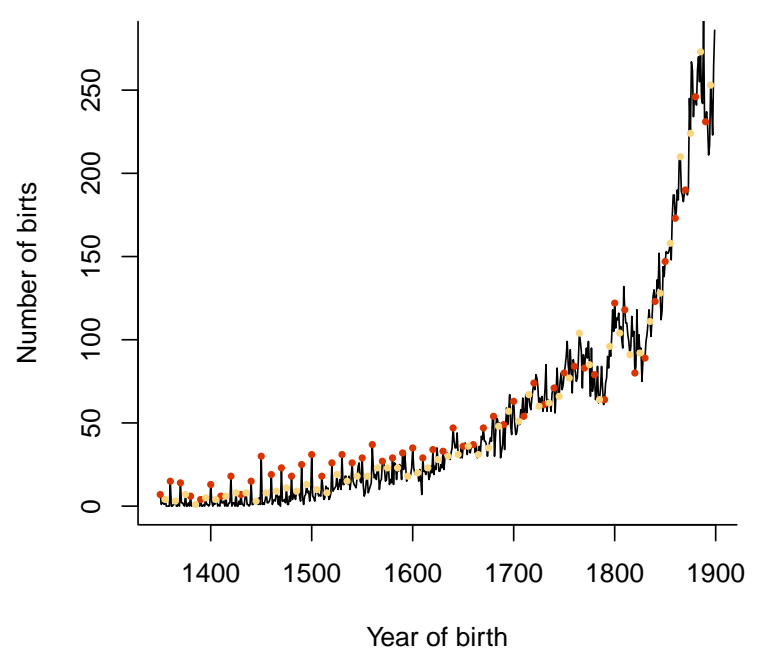

(a) All scholars with known birth year

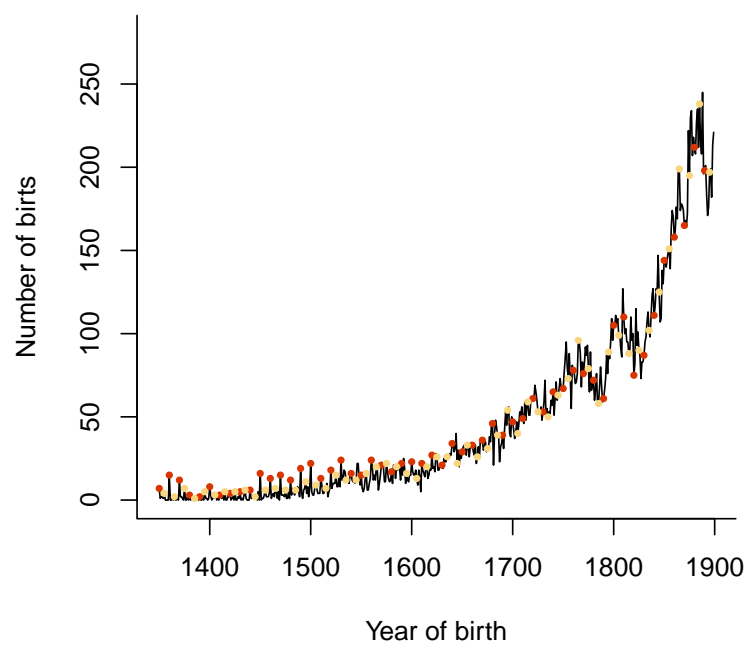

(c) Scholars from sources in Cat. $1 \& 2$

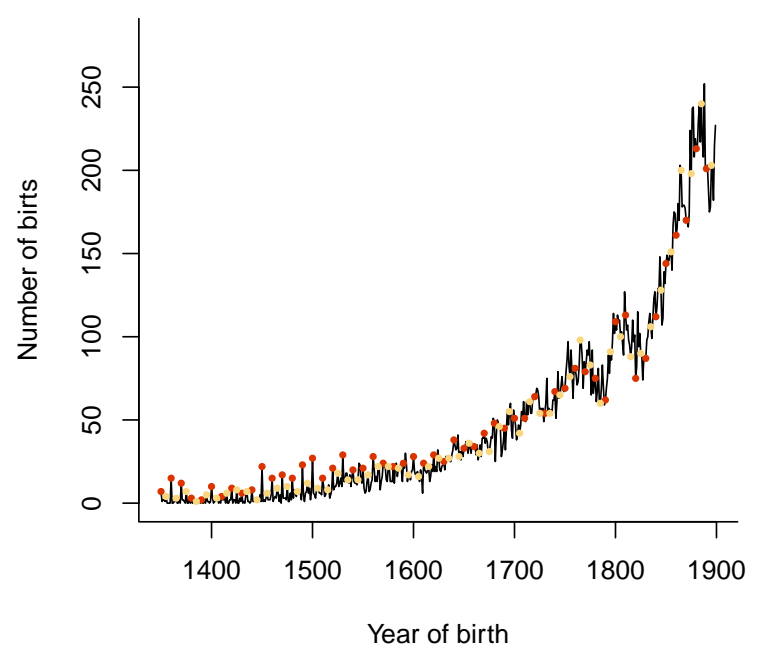

(b) Scholars in the baseline mortality estimation

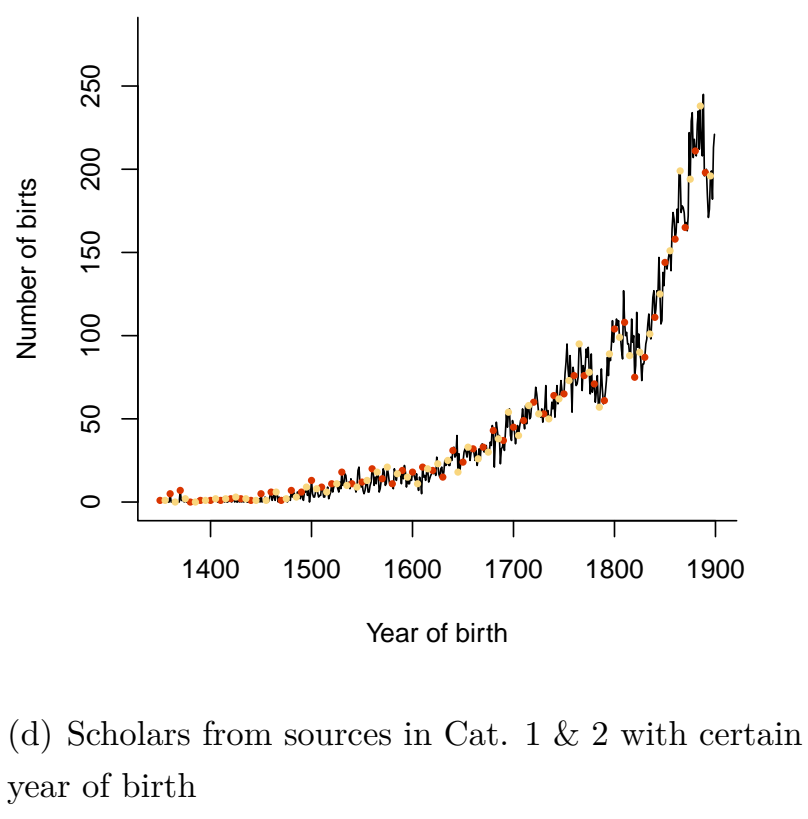

Fig. A1. Number of observations by birth year 


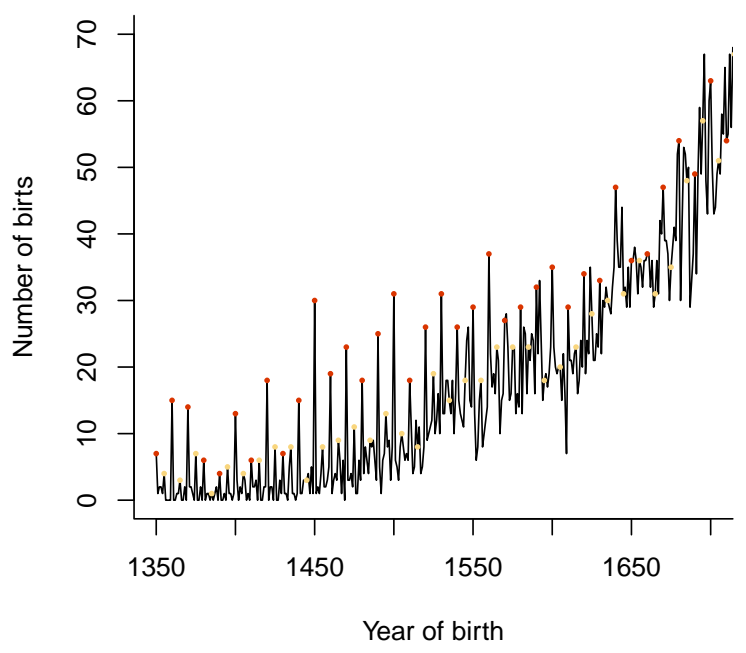

(a) All scholars with known birth year

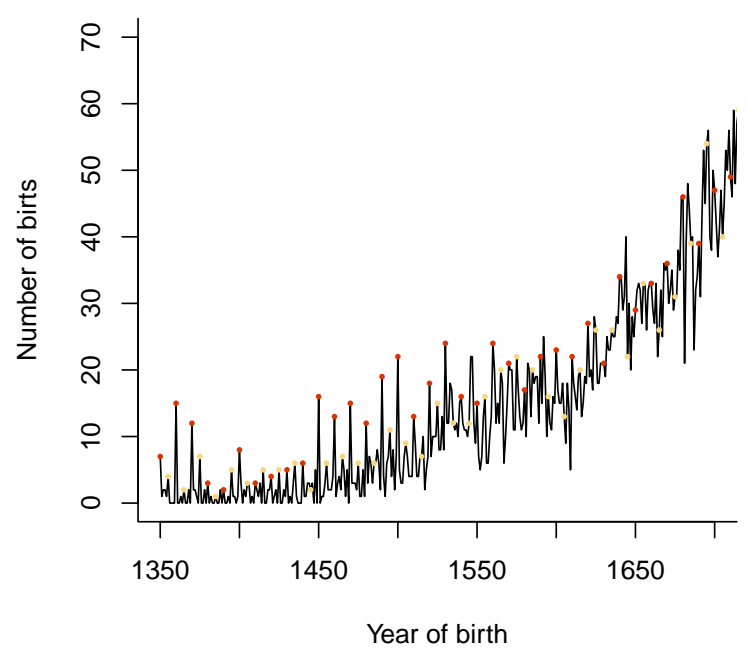

(c) Scholars from sources in Cat. $1 \& 2$

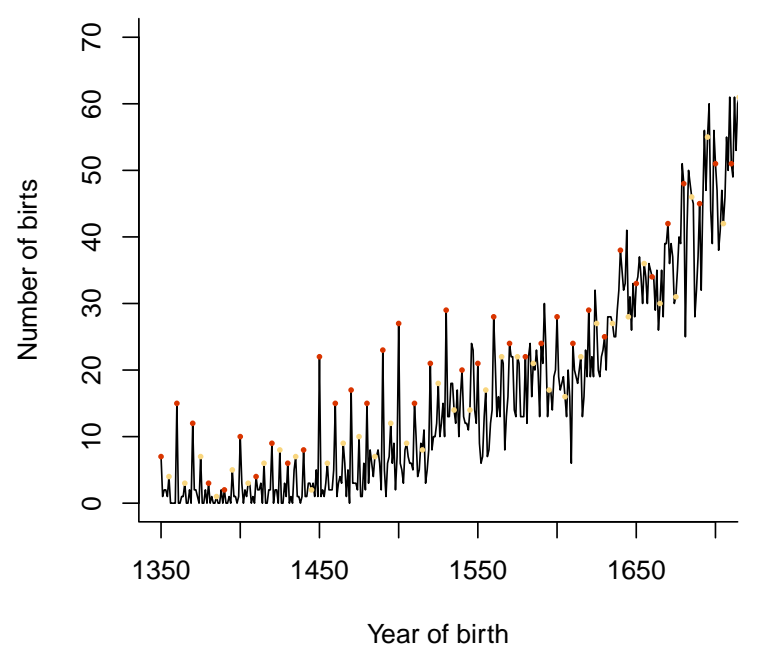

(b) Scholars in the baseline mortality estimation

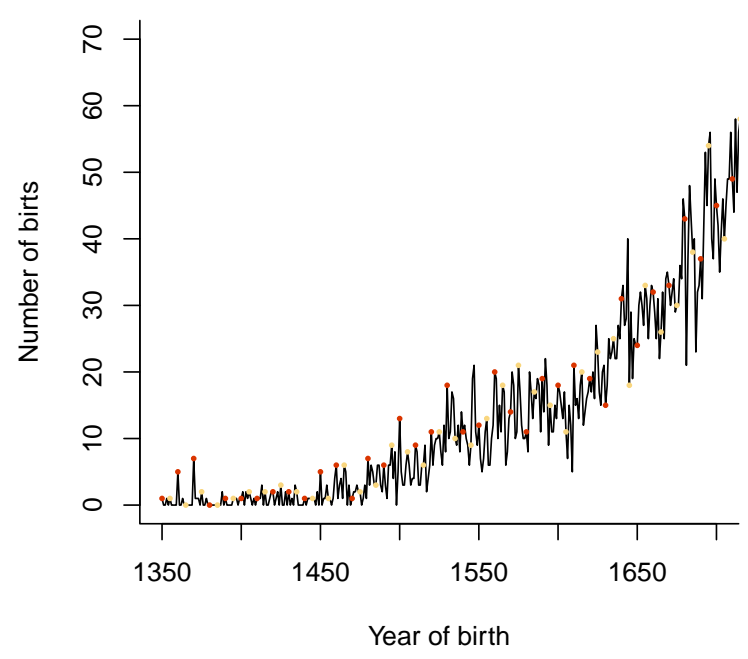

(d) Scholars from sources in Cat. 1 \& 2 with certain year of birth

Fig. A2. Number of observations by birth year until 1700 


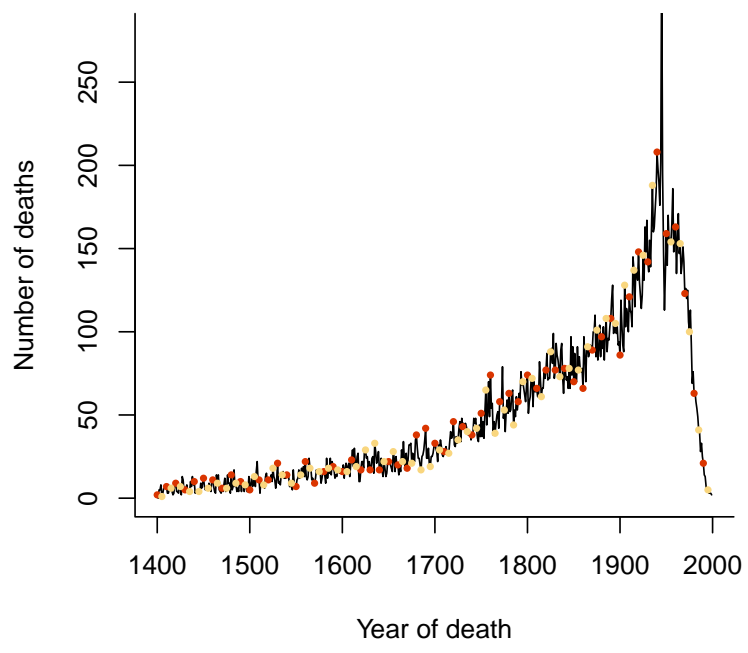

(a) All scholars with known death year

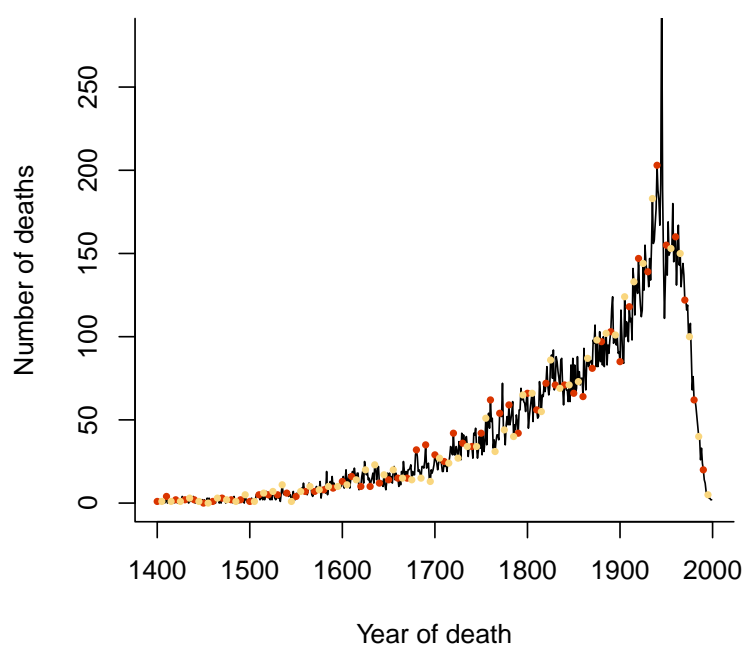

(c) Scholars from sources in Cat. $1 \& 2$

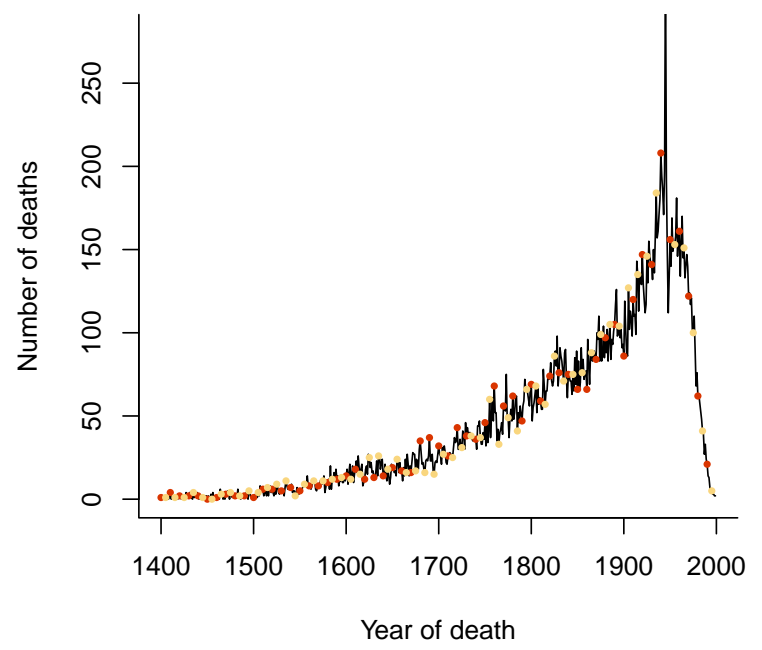

(b) Scholars in the baseline mortality estimation

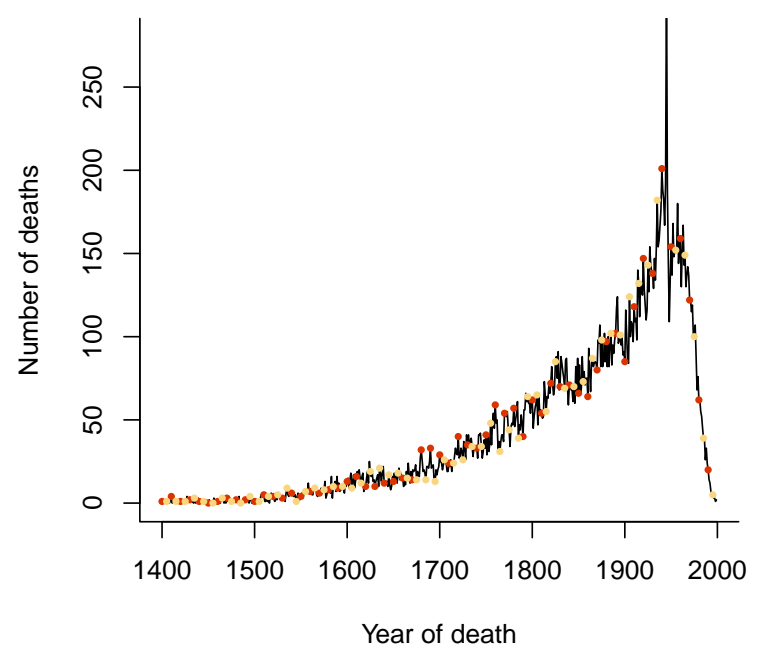

(d) Scholars from sources in Cat. 1 \& 2 with certain year of death

Fig. A3. Number of observations by death year 


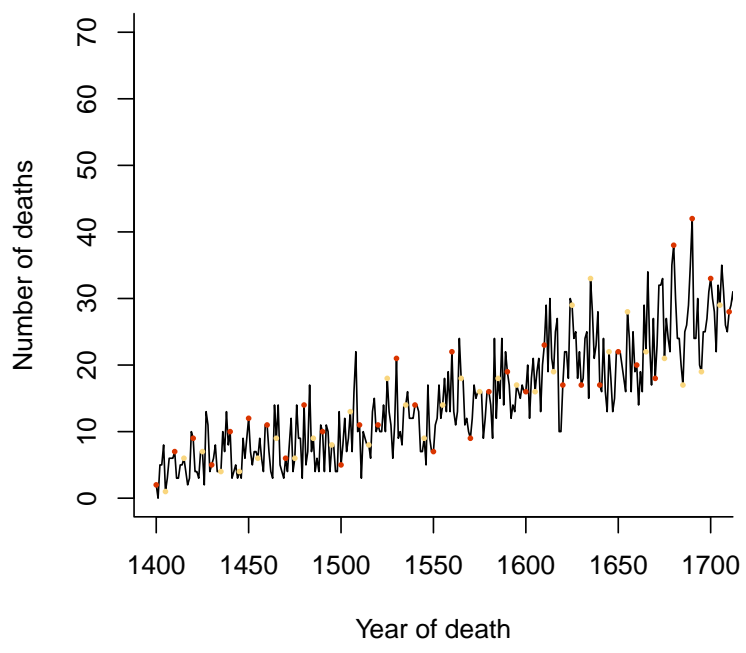

(a) All scholars with known death year

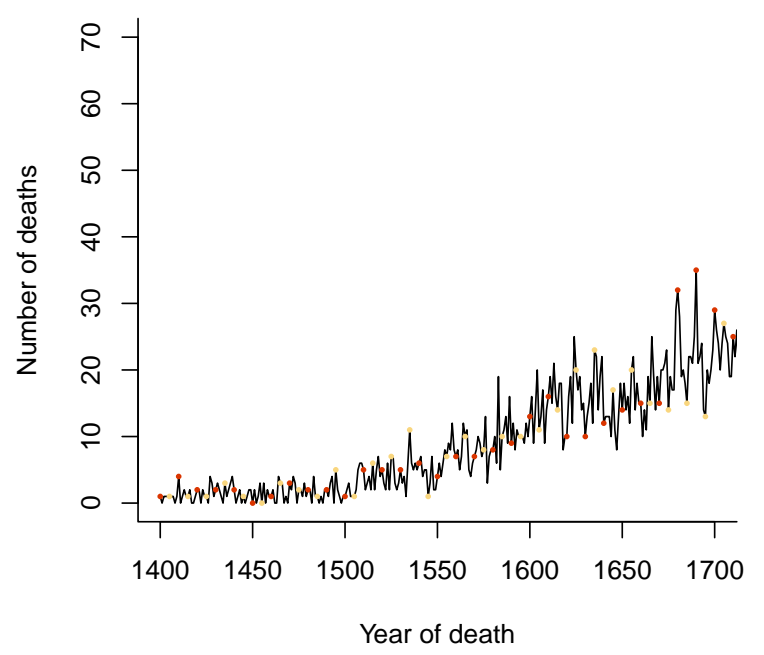

(c) Scholars from sources in Cat. $1 \& 2$

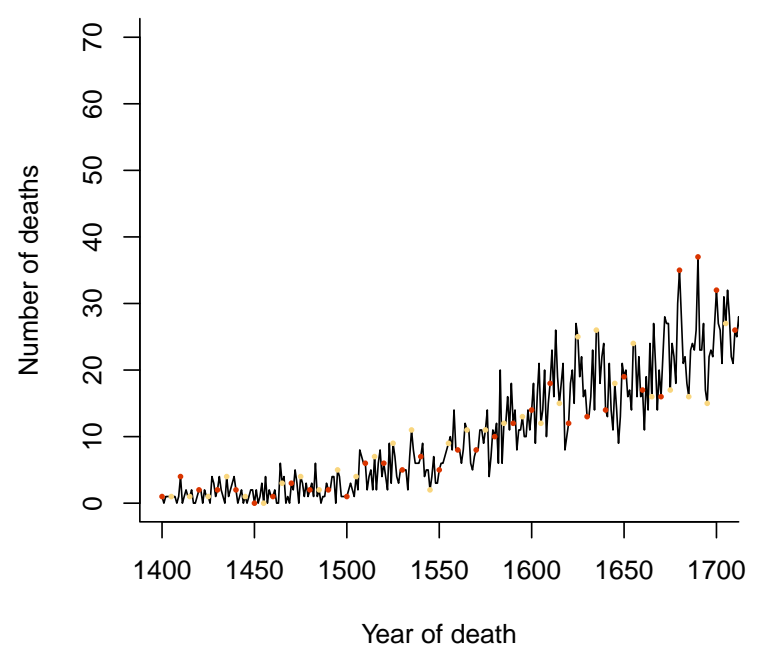

(b) Scholars in the baseline mortality estimation

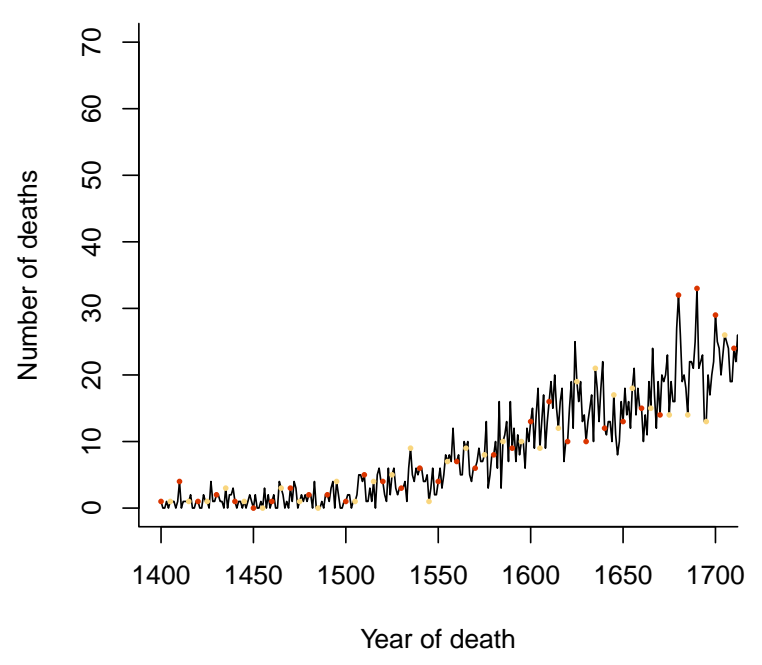

(d) Scholars from sources in Cat. $1 \& 2$ with certain year of death

Fig. A4. Number of observations by death year until 1700 


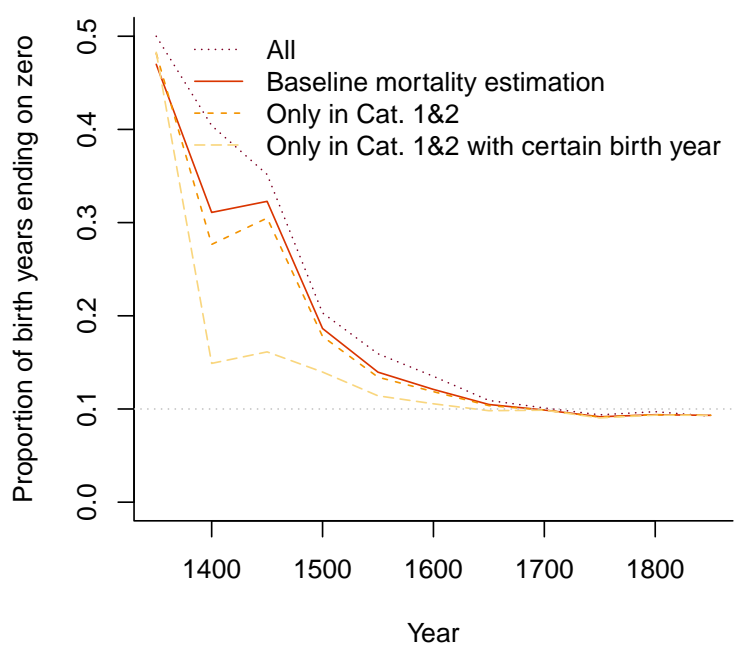

(a) Proportion of birth years ending on zero

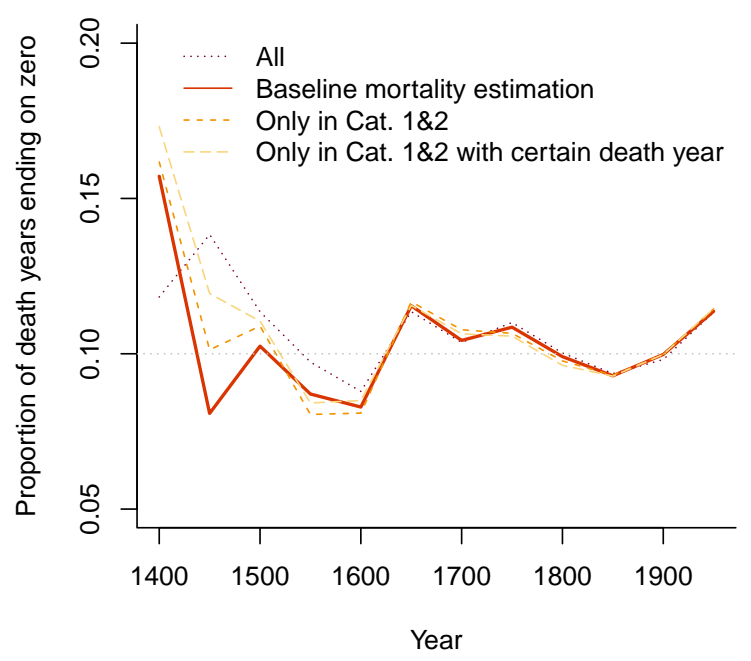

(c) Proportion of death years ending on zero

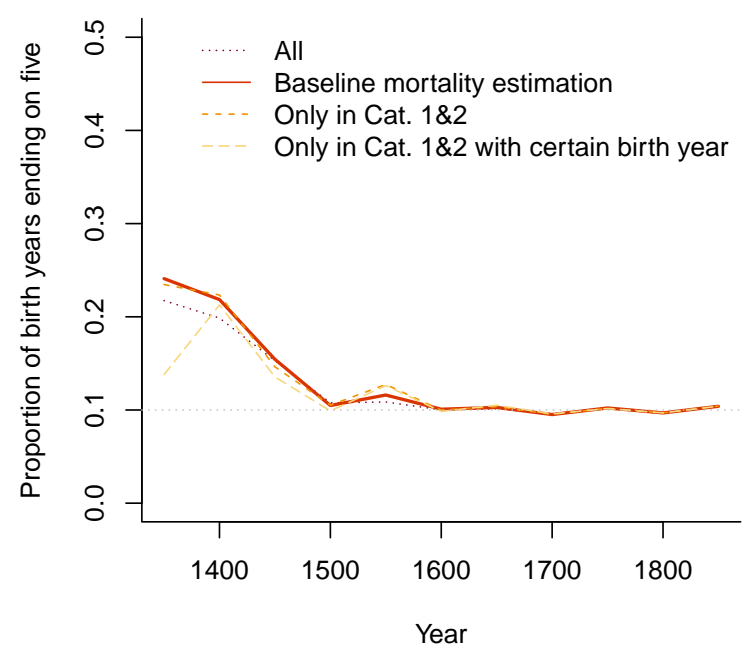

(b) Proportion of birth years ending on five

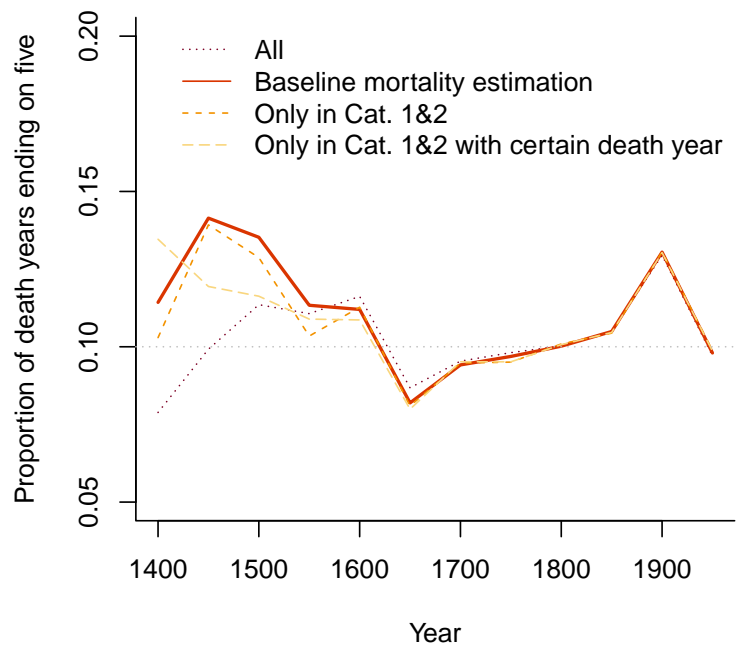

(d) Proportion of death years ending on five

Fig. A5. Birth and death years ending on zero or five in the population of scholars 
Tab. A2: Adjusted Whipple-Index to measure birth and death year heaping

\begin{tabular}{|c|c|c|c|c|c|c|c|c|c|c|c|c|}
\hline \multirow{3}{*}{ Period } & \multicolumn{6}{|c|}{ Birth year heaping } & \multicolumn{6}{|c|}{ Death year heaping } \\
\hline & \multicolumn{2}{|c|}{ All } & \multicolumn{2}{|c|}{$\begin{array}{l}\text { With year of birth, } \\
\text { nom. \& death or exit }\end{array}$} & \multicolumn{2}{|c|}{$\begin{array}{l}\text { With certain } \\
\text { year of birth }\end{array}$} & \multicolumn{2}{|c|}{ All } & \multicolumn{2}{|c|}{$\begin{array}{l}\text { With year of birth, } \\
\text { nom. \& death or exit }\end{array}$} & \multicolumn{2}{|c|}{$\begin{array}{l}\text { With certain } \\
\text { year of birth }\end{array}$} \\
\hline & All cat. & $\begin{array}{l}\text { Cat. } \\
1 \& 2\end{array}$ & All cat. & $\begin{array}{l}\text { Cat. } \\
1 \& 2\end{array}$ & All cat. & $\begin{array}{l}\text { Cat. } \\
1 \& 2\end{array}$ & All cat. & $\begin{array}{l}\text { Cat. } \\
1 \& 2\end{array}$ & All cat. & $\begin{array}{l}\text { Cat. } \\
1 \& 2\end{array}$ & All cat. & $\begin{array}{l}\text { Cat. } \\
1 \& 2\end{array}$ \\
\hline $1348-1397$ & 324.2 & 325.8 & 313.3 & 314.8 & 293.1 & 293.1 & 204.5 & 204.5 & 272.7 & 272.7 & 250.0 & 250.0 \\
\hline $1398-1447$ & 312.1 & 295.5 & 280.2 & 266.3 & 196.4 & 184.8 & 100.4 & 95.3 & 146.2 & 142.9 & 170.0 & 166.7 \\
\hline $1448-1497$ & 256.2 & 235.0 & 244.6 & 234.4 & 157.0 & 153.3 & 119.4 & 122.4 & 111.1 & 118.8 & 107.6 & 119.4 \\
\hline $1498-1547$ & 159.8 & 150.7 & 152.7 & 146.6 & 127.0 & 123.8 & 113.3 & 109.9 & & 118.7 & & 115.4 \\
\hline $1548-1597$ & 135.7 & 139.3 & 133.8 & 137.1 & 117.8 & 123.3 & 106.4 & 103.5 & 102.6 & 94.7 & 107.1 & 99.5 \\
\hline $1598-1647$ & & 116.1 & 116.0 & 113.7 & 105.8 & 104.4 & 102.5 & 102.7 & 98.5 & 98.0 & 95.4 & 97.3 \\
\hline $1648-1697$ & 107.3 & 106.6 & 106.1 & 106.1 & 102.3 & 103.6 & 101.9 & 102.5 & 101.3 & 101.3 & 100.2 & 100.6 \\
\hline $1698-1747$ & 99.7 & 99.9 & 98.8 & 99.2 & 97.8 & 98.7 & 100.8 & 102.9 & 100.2 & 102.5 & 100.3 & 102.0 \\
\hline $1748-1797$ & 100.0 & 99.5 & 99.5 & 99.1 & 98.3 & 98.1 & 105.8 & 104.2 & 103.8 & 101.7 & 103.3 & 101.3 \\
\hline $1798-1847$ & 97.6 & 97.6 & 96.8 & 97.0 & 96.3 & 96.5 & 101.3 & 100.7 & 100.5 & 100.2 & 99.9 & 99.5 \\
\hline $1848-1897$ & 101.0 & 101.1 & 100.4 & 100.5 & 100.2 & 100.4 & 99.7 & 99.6 & 99.4 & 99.3 & 99.1 & 99.2 \\
\hline $1898-1947$ & & & & & & & & 115.0 & & 116.3 & 116.0 & \\
\hline 1948-1997 & & & & & & & 100.0 & 100.7 & 100.5 & 101.2 & 100.5 & 101.2 \\
\hline
\end{tabular}

A Whipple-Index smaller than 105 indicates very high data quality (dark green). The data are relatively accurate in a range of 105-110 (light green); fairly okay in a range of 110-125 (yellow), poor in a range of 125-175 (orange), and very poor if the values exceed 175 (red). 


\section{A.3 Life Expectancy}

\section{A.3.1 Life Expectancy and the Conditional Age}

Even if we observe first appointments below age 20, a sufficiently large population at risk is required to obtain convincing estimations of life expectancy $E_{x, t}$ conditional to the corresponding ages $x$ at time $t$. Using 25-year rolling intervals, Fig. A6a illustrates the increasing first appointment age over time. The year always marks the middle of the 25-year rolling interval; e.g. 1550 covers 1538-1562. Indeed, in the early sixteenth century, more than $25 \%$ of all first appointments were made below age 25. For around 350 years thereafter, the 25\%-quantile remained rather stable, at between ages 27 and 30; and then increased at the end of the period under investigation. The increasing trend in the first appointment age is more evident when we look at the median and the 75\%-quantile. Between 1500 and 1900, the median age increased from 30 to 36 . Compared to similar exercises in the literature for instance, Fornasin et al. (2010) and Andreev et al. (2011) - we find that the average appointment age of scholars was rather low and stable, which allows us to end our analysis at younger ages.

As in all periods except the early twentieth century at least $25 \%$ of all first appointments occurred before age 30, we have decided to fix the initial age for life table calculations at age 30. Furthermore, adding the median, the $25 \%$-quantile, and the $75 \%$-quantile age at death in Fig. A6b illustrates that, on average, we are able to observe scholars for rather long age spans. The gap between the median age at death and the median age at appointment is between 24 and 35 years. In the subsample of scholars in scientific academies, the median ages at death and at first appointment are even higher, although the difference is greater for the age of appointment.

An alternative approach for determining the optimal $x$ relates the difference between upper and lower $95 \%$ confidence intervals, $C I_{x, t}^{\text {low }}$ and $C I_{x, t}^{\text {high }}$, to the corresponding life expectancy $E_{x, t}$ and, then computes the age that minimizes this value:

$$
\operatorname{argmin}_{x}\left\{\frac{1}{T} \sum_{t}^{T} \frac{C I_{x, t}^{\mathrm{high}}-C I_{x, t}^{\mathrm{low}}}{E_{x, t}}\right\}
$$

with $\mathrm{T}$ as the number of 25-year rolling time intervals. The initial period of 1400 covers all cohorts born in 1388-1412, and the last period covers all cohorts born in 1875-1899. The rare and scattered observations for the period before 1388 are not included. Hence, we have chosen the age $\mathrm{x}$ that minimizes the relative average $95 \%$ confidence interval. Proceeding in five-year age steps, this procedure leads to age 30 . 


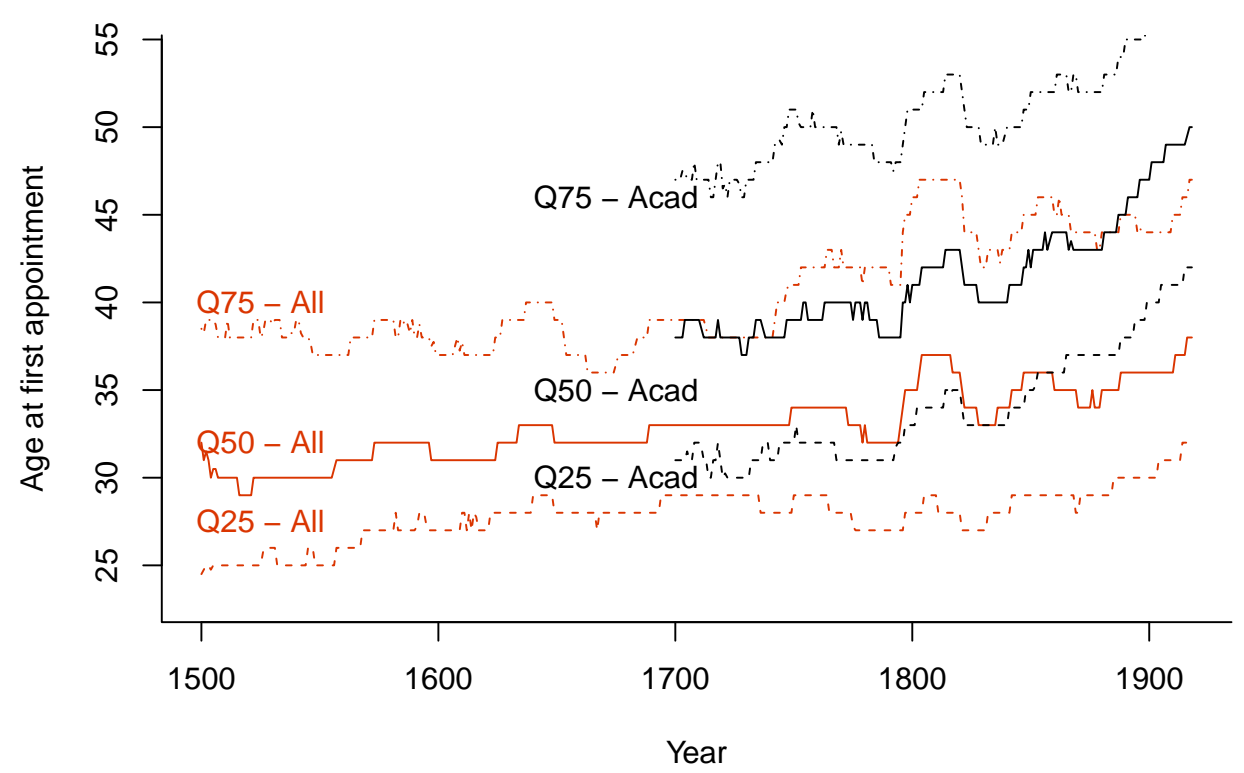

(a) Age at first appointment

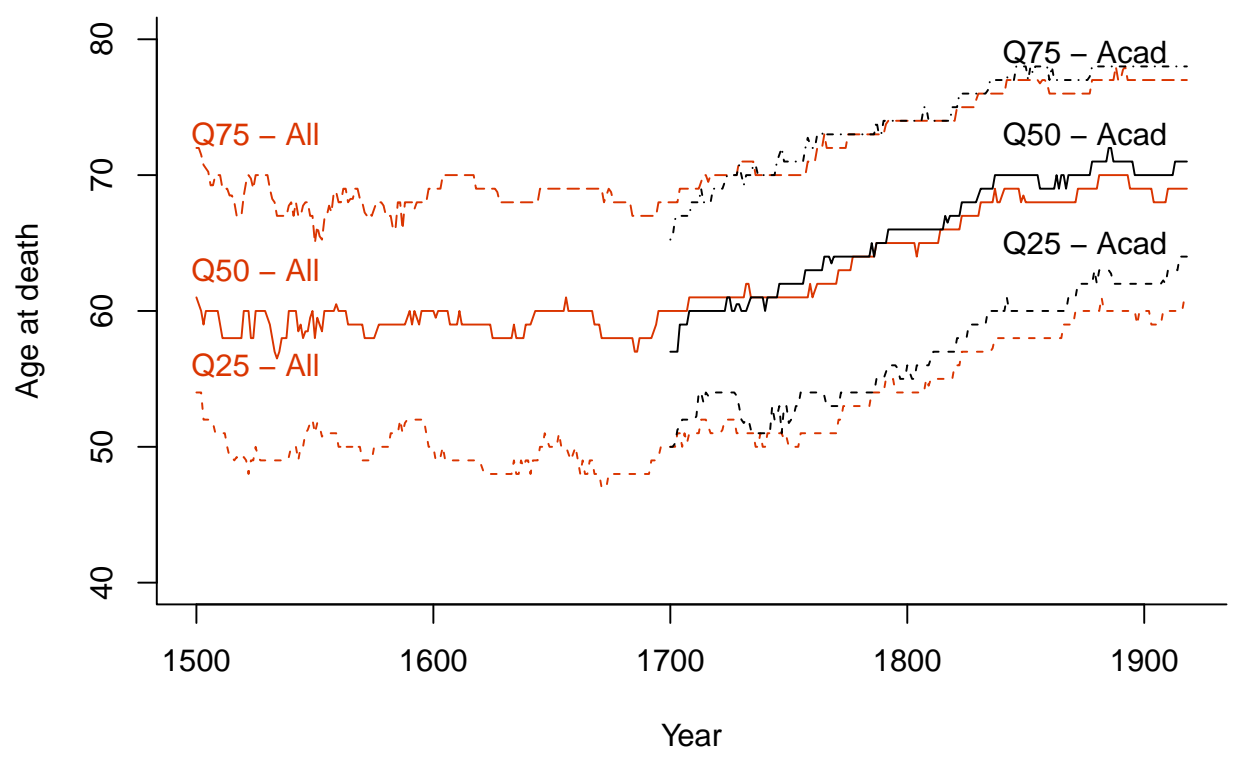

(b) Age at death

Fig. A6. The dynamics of age at appointment and age at death in 25-year rolling intervals 


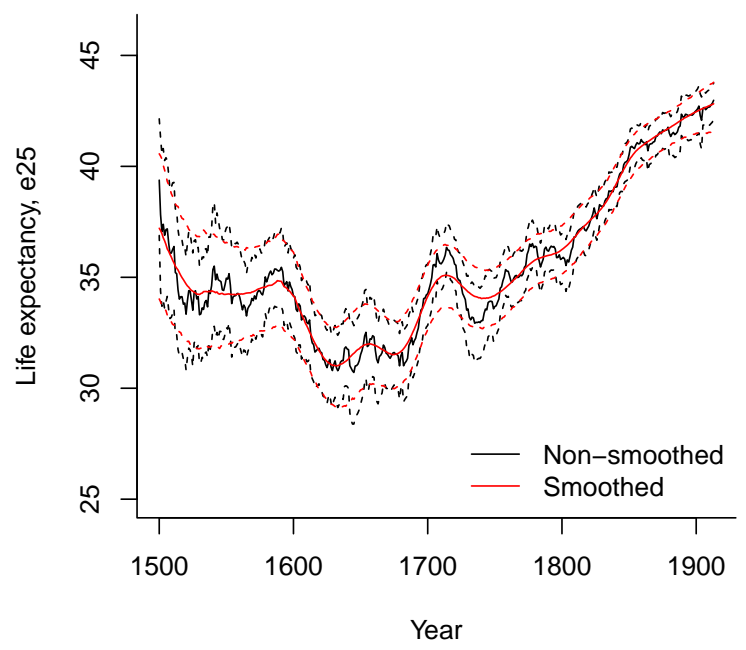

(a) Life expectancy at age 25

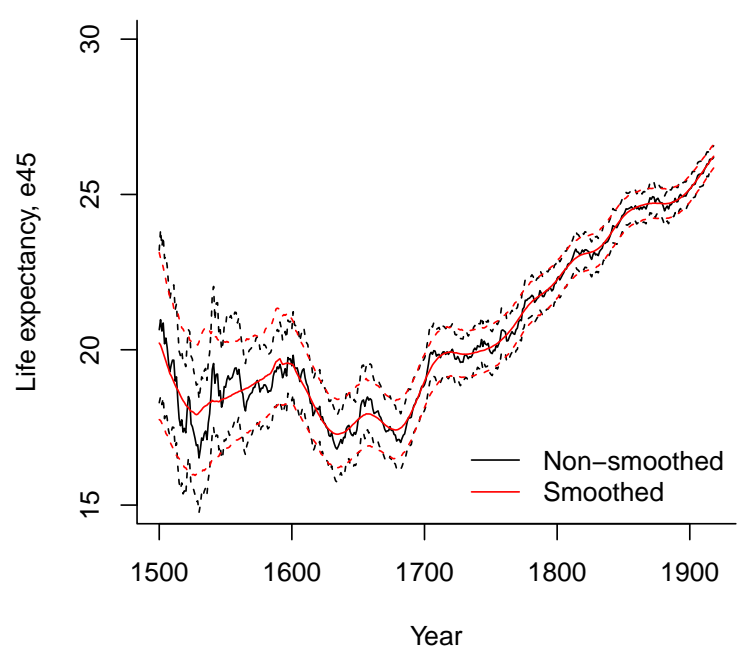

(c) Life expectancy at age 45

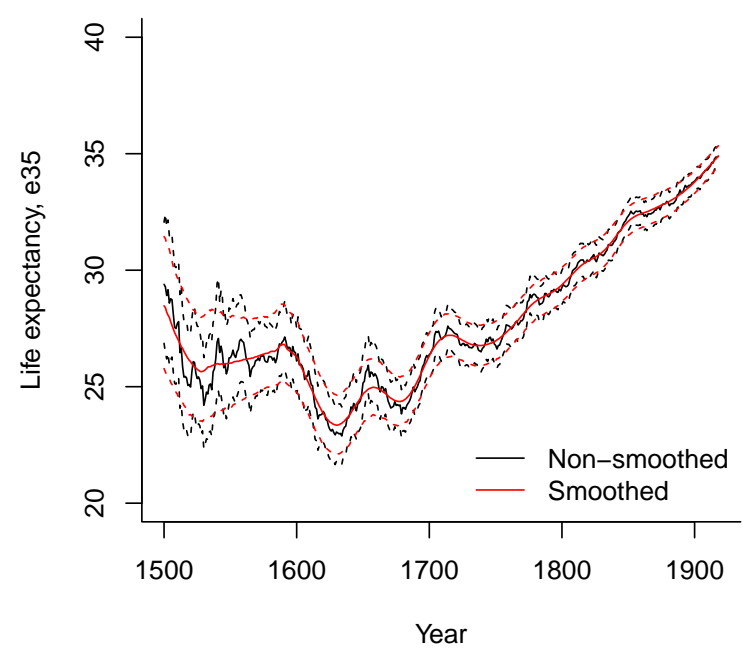

(b) Life expectancy at age 35

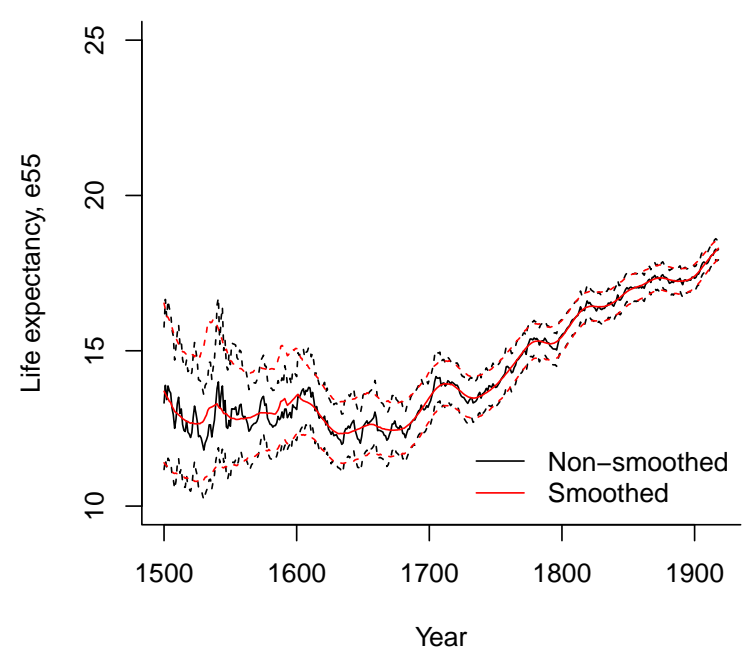

(d) Life expectancy at age 55

\section{Fig. A7. Dynamics of life expectancy at various ages}

Figure A7 applies 25-year rolling intervals and two-dimensional smoothed data. Dashed lines mark 95\% confidence intervals.

In addition to the baseline age 30, which is presented from the period perspective in Section 3.1 and from the cohort perspective in Section 3.2, Fig. A7 illustrates the mortality dynamics for life expectancy conditional to ages $25,35,45$, and 55 . 


\section{A.3.2 Additional Figures on the Robustness of Life Expectancy Dynamics}

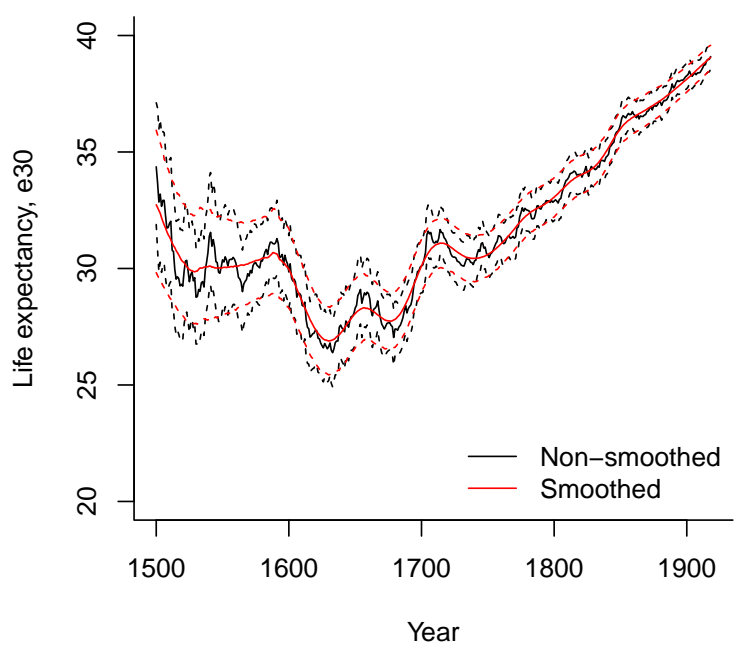

(a) Baseline estimation

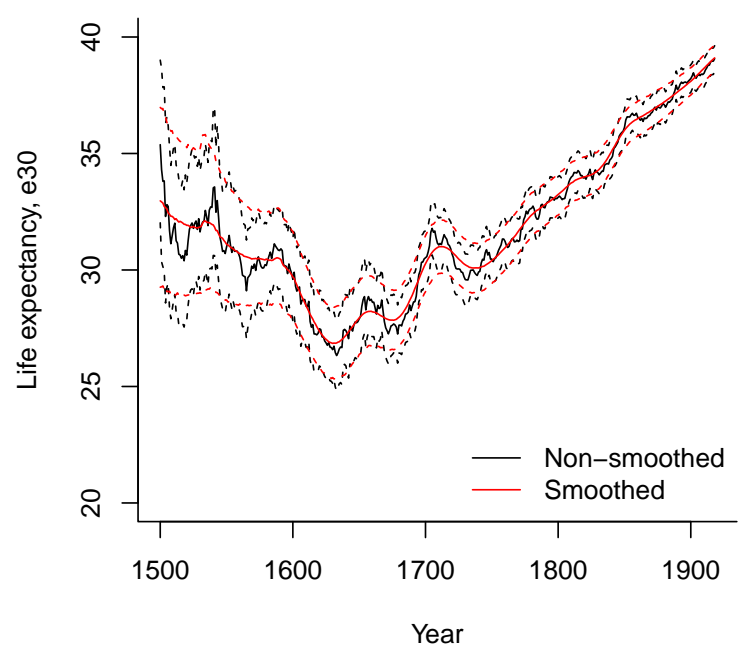

(c) Estimation including only observations in Cat. 1 $\& 2$

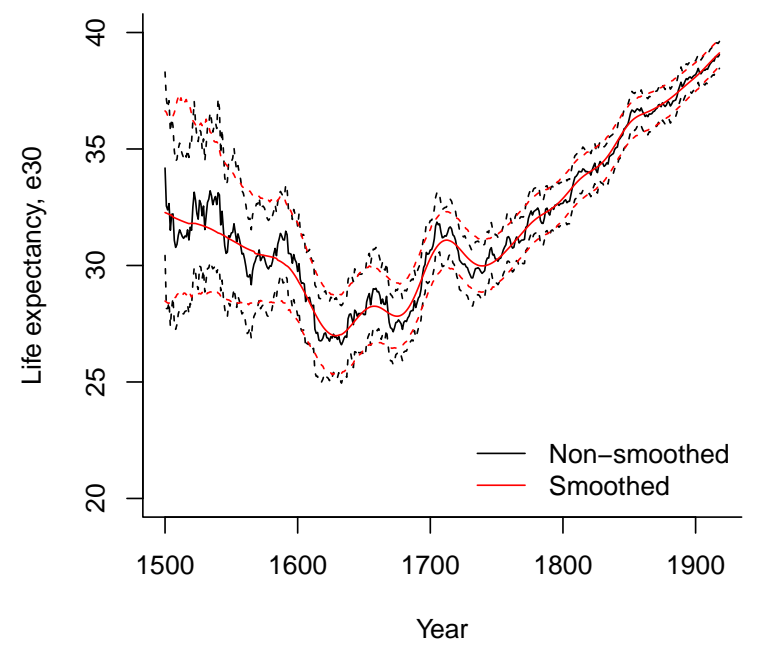

(b) Estimation including only observations with certain birth year

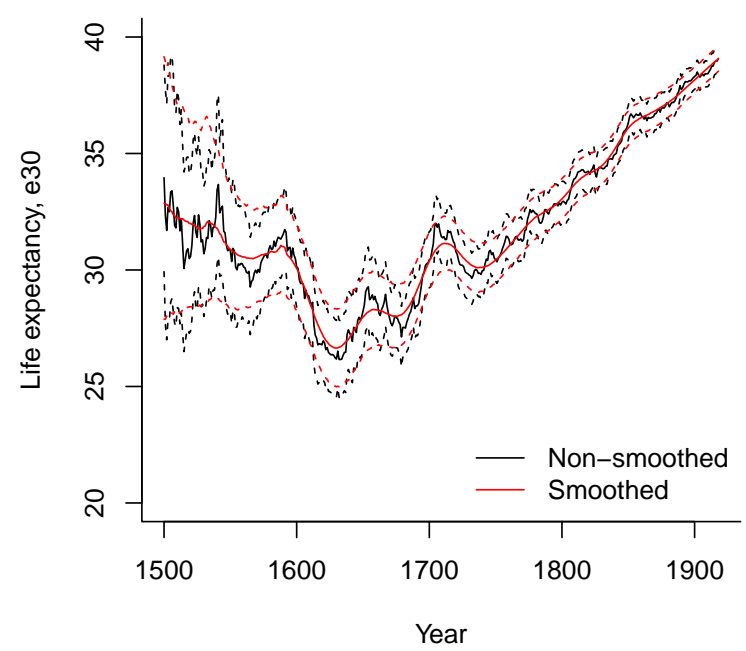

Fig. A8. Dynamics of life expectancy according to the data quality

Figure A8 applies 25-year rolling intervals and two-dimensional smoothed data. Dashed lines mark 95\% confidence intervals. 


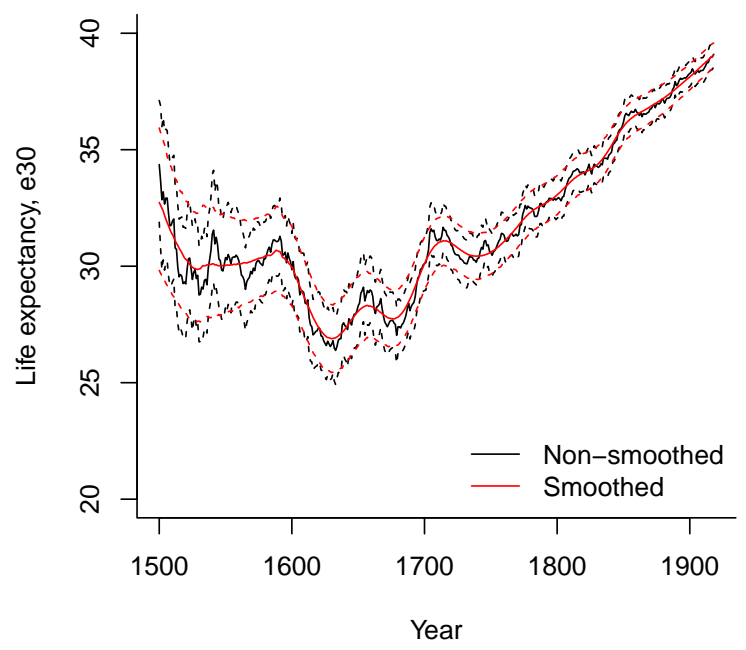

(a) Baseline estimation

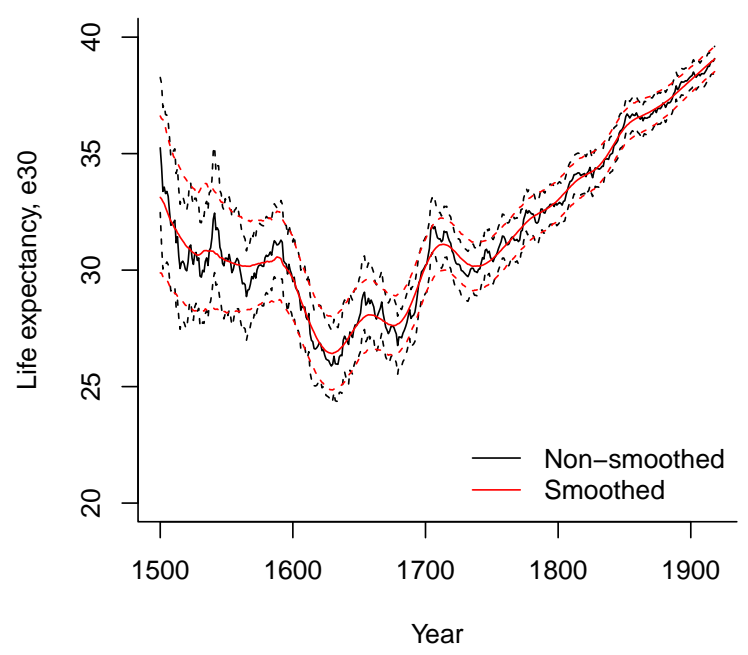

(c) Estimation without birth years ending on five

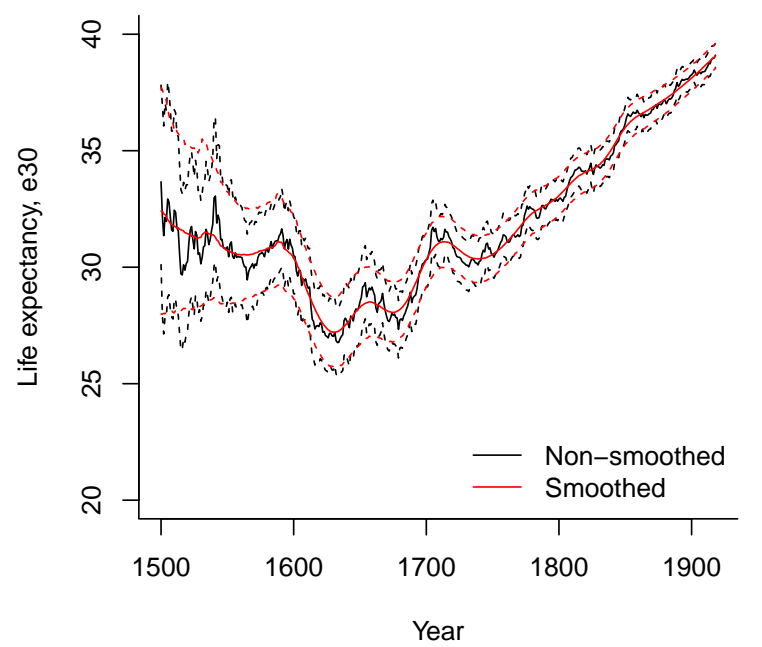

(b) Estimation without birth years ending on zero

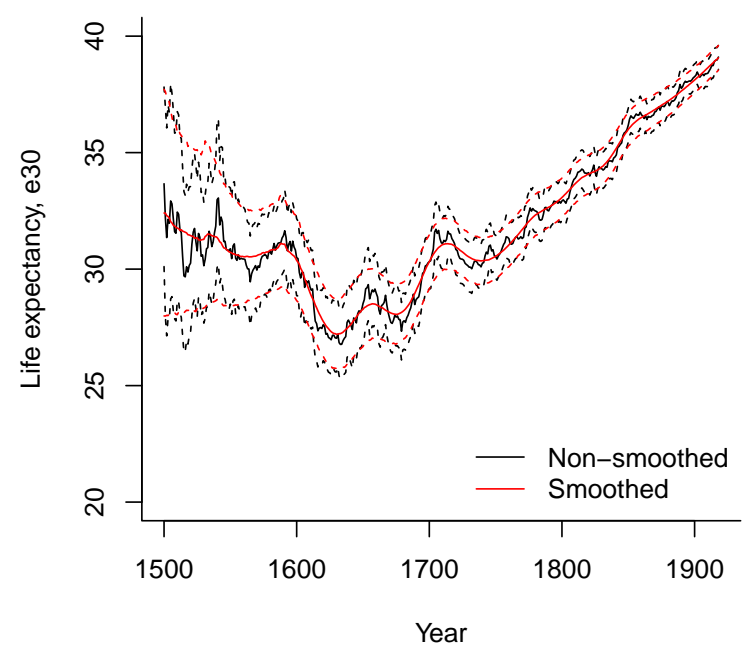

(d) Estimation without birth years ending on zero and five

\section{Fig. A9. Dynamics of life expectancy excluding potential birth year heaping}

Figure A9 applies 25-year rolling intervals and two-dimensional smoothed data. Dashed lines mark 95\% confidence intervals. 


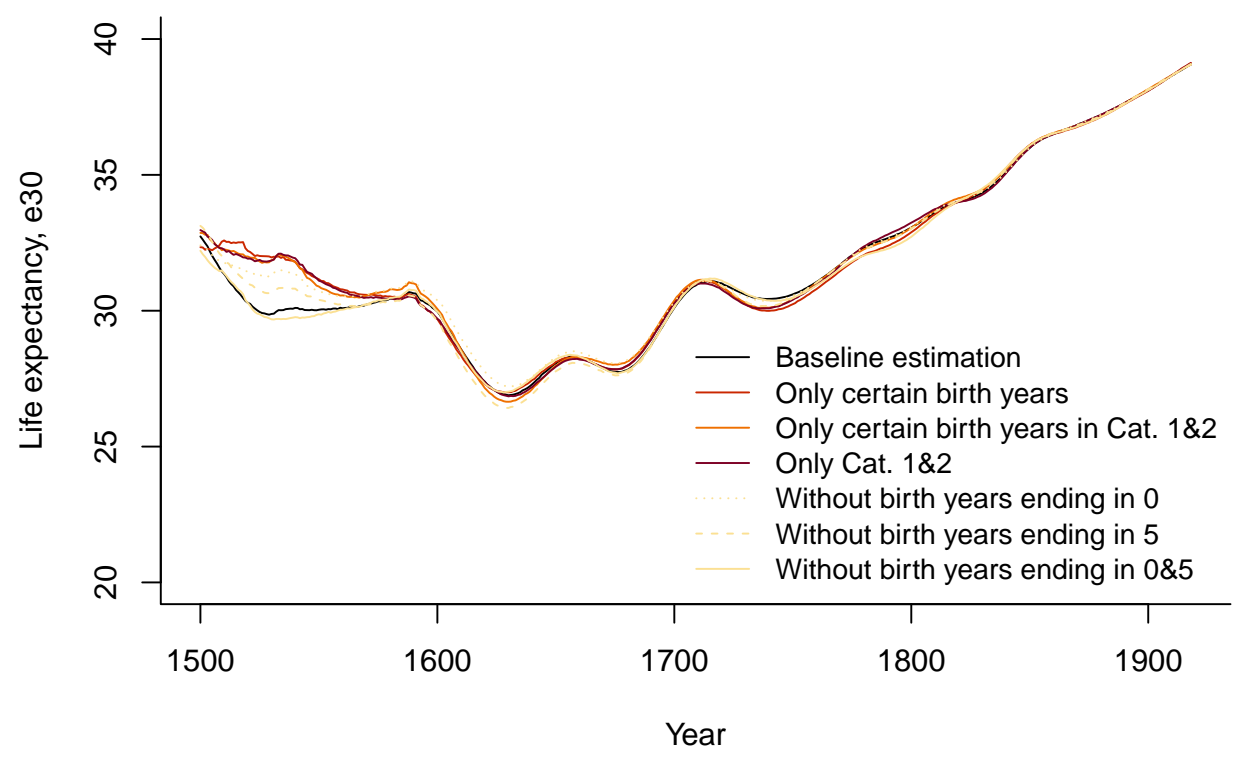

(a) Smoothed life expectancy

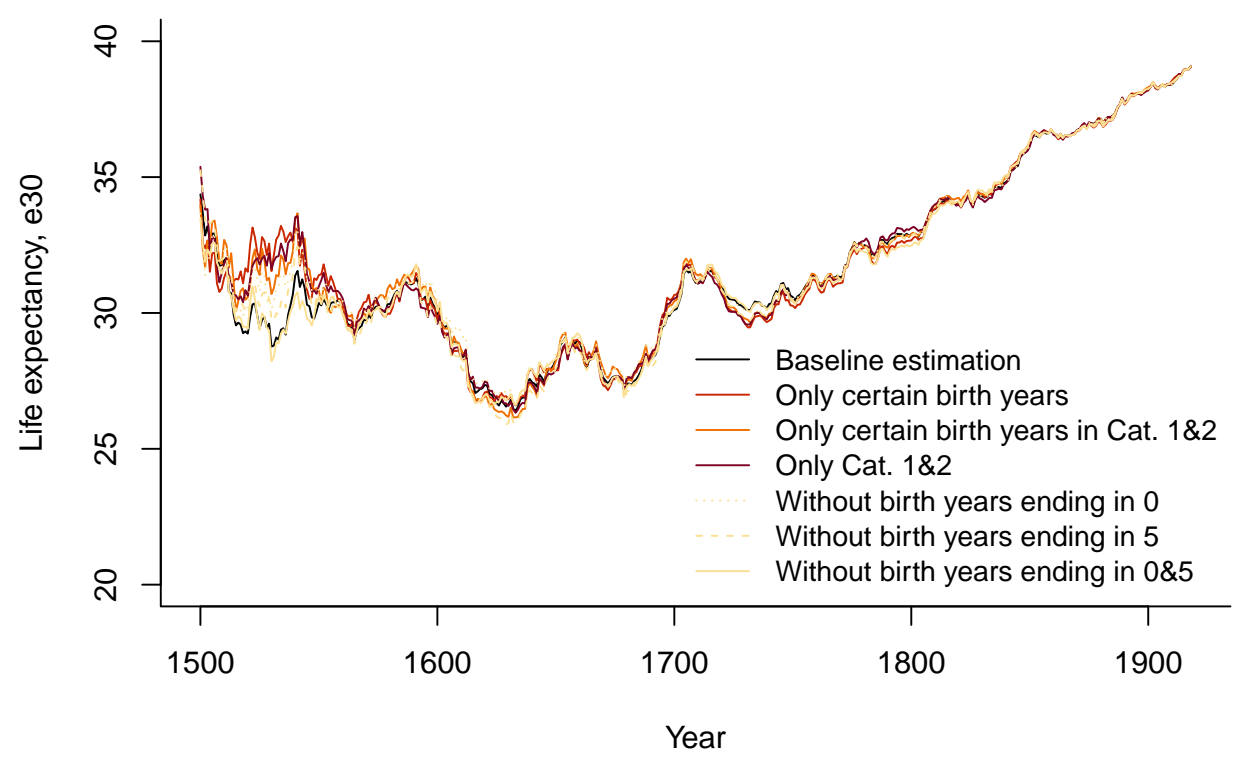

(b) Non-smoothed life expectancy

Fig. A10. Summary of life expectancy at age 30 according to data quality Figure A10 applies 25-year rolling intervals and two-dimensional smoothed data. 


\section{A.3.3 Additional Figures on Medicine, Academies, and Life Expectancy}

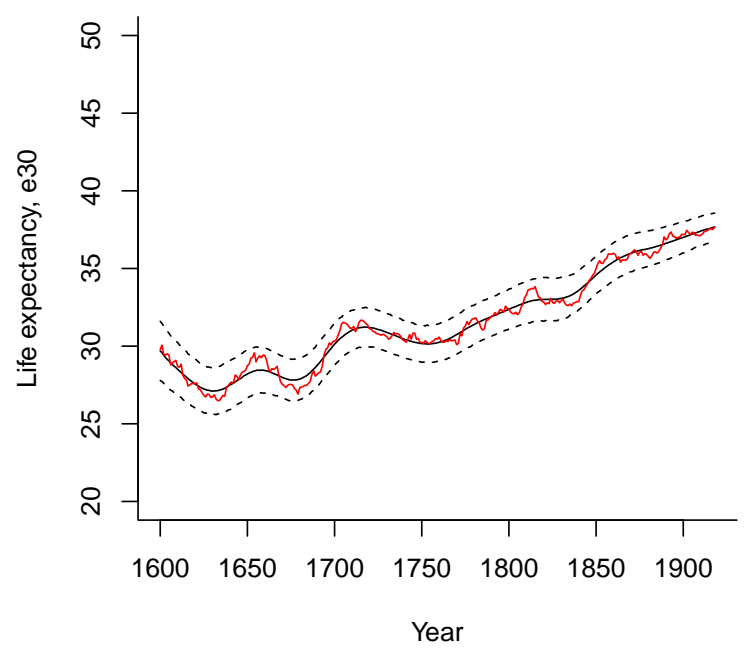

(a) Non-medicine \& University

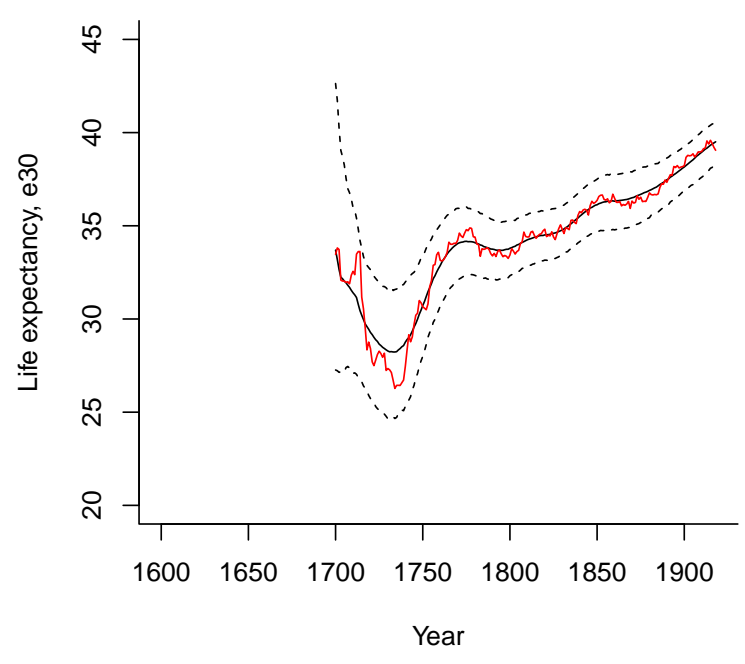

(c) Non-medicine \& Academy

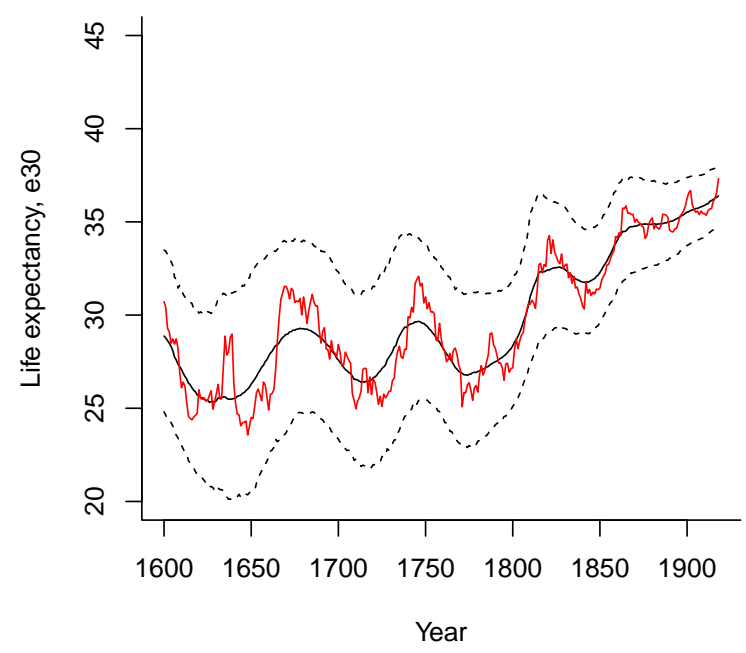

(b) Medicine \& University

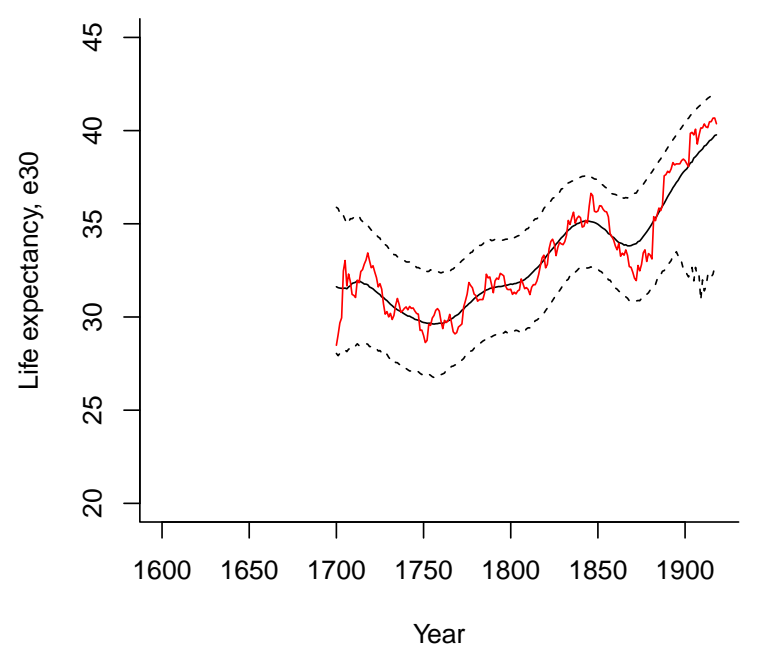

(d) Medicine \& Academy

Fig. A11. Dynamics of life expectancy according to social status and field of science

Figure A11 applies 25-year rolling intervals and two-dimensional smoothed data. Dashed lines mark 95\% confidence intervals. 


\section{A.4 A Brief History of Universities}

The characteristics of our institutions and their members evolved over time. At the very beginning of our study period, in the late medieval age, the structure of universities differed considerably from that of modern institutions, which had consequences for the income and social status of scholars. The characteristics of scholars evolved accordingly.

A typical full university had a lower faculty of Arts and three higher faculties: Medicine, Theology, and Law. Scholars in the higher faculties also had higher incomes. While universities were rather independent at that time, it was common for teachers at the theological faculty to belong to a religious order. Academic titles mainly signaled that a person was a master in his field, and was linked to prestige and high social status. However, the incomes of scholars were generally rather low (Verger, 2003).

Until the end of the eighteenth century, a variety of positions, such as ordinary and extraordinary professors, doctors, and lectors, existed. These positions came with different obligations and responsibilities, and with different privileges and salaries. While all scholars enjoyed a variety of privileges - such as a special jurisdiction, tax and dress privileges, or the right to carry weapons - they lost much of their medieval freedom. Salaries remained generally low, and were often not paid regularly. Thus, it was quite common for scholars from higher faculties to work in the profession they taught. Scholars from lower faculties often held positions at schools. Incomes and privileges varied across universities. Moreover, a doctoral degree was not always required for academic positions, and the obligation to publish varied considerably. Appointments driven by kinship were rather common at universities like Gießen or Tübingen (Vandermeersch, 2003).

With the crisis of universities in the second half of the eighteenth century - the population of students declined drastically - and the emergence of the German university model, institutions changed rapidly. In the first half of the nineteenth century, payments in kind ended, salaries increased and were paid regularly. Thus, working at a university became a full-time job. The introduction of scientific standards in the process of appointments gradually reduced the role of kinship. However, kinship was still important at several universities, such as the University of Kiel. Thus, it was a period of social change toward the emergence of an academic elite. Scholars were envisioning themselves as scientists. Privileges and the role of professor dynasties declined, while the social status of tenured professors increased (Klinge, 2004; McClelland, 1988).

\section{A.5 Online Professor Catalogs}


Tab. A3: Overview of the professor catalogs available online and used

\begin{tabular}{|l|l|l|}
\hline \hline University & Catalogue & Link \\
\hline University of Rostock & Catalogus Professorum Rostochiensium & http://cpr.uni-rostock.de/ \\
Leipzig University & Catalogus Professorum Lipsiensium & https://research.uni-leipzig.de/catalogus-professorum-lipsiensium/ \\
University of Marburg & Marburger Professorenkatalog & https://www.uni-marburg.de/uniarchiv/pkat \\
University of Helmstedt & Professorenkatalog Helmstedt & http://uni-helmstedt.hab.de/ \\
University of Kiel & Kieler Professorenkatalog & https://cau.gelehrtenverzeichnis.de/ \\
Leiden University & Leidse Hoogleraren anaf 1575 & https://hoogleraren.leidenuniv.nl/ \\
University of Groningen & Catalogus Prof. Academiae Groninganae & https://hoogleraren.ub.rug.nl/ \\
University of Amsterdam & Album Academicum & http://www.albumacademicum.uva.nl/ \\
Utrecht University & Catalogus Prof. Academiæ Rheno-Traiectinæ & https://profs.library.uu.nl/ \\
University of Mainz & Gutenberg Biographics & http://gutenberg-biographics.ub.uni-mainz.de/home.html/ \\
University of Halle & Catalogus Professorum Halensis & https://www.catalogus-professorum-halensis.de/ \\
\hline \hline
\end{tabular}




\section{References in online appendices}

Albrecht, H. (1986). Catalogus professorum der Technischen Universität CaroloWilhelmina zu Braunschweig: Teil 1. Lehrkräfte am Collegium Carolinum 1745-187r. Braunschweig: Universitätsbibliothek.

Andreev, E. M., Jdanov, D., Shkolnikov, V. M. and Leon, D. A. (2011). Longterm trends in the longevity of scientific elites: Evidence from the British and the Russian academies of science. Population Studies, 65 (3), 319-334.

Archiv der Universität Halle-Wittenberg (2019). Catalogus Professorum Halensis, https://www. catalogus-professorum-halensis.de/.

Archiv Leopoldina (2019). Mitglieder seit 1652, https://www.leopoldina.org/ mitglieder/mitglieder-seit-1652//.

Auerbach, I. and Gundlach, F. (1979). Catalogus professorum academiae Marburgensis: Die akademischen Lehrer der Philipps-Universität Marburg. Marburg: Elwert.

BAuer, J. J. (1957). Zur Frühgeschichte der Theologischen Fakultät der Universität Freiburg i. Br.(1460-1620): Universität Freiburg im Breisgau 1457-195\%. Gabe d. Theologischen Fakultät. Freiburg: Albert.

Bayerische Akademie der Wissenschaften (2019). Verstorbene Mitglieder, https: //badw.de/gelehrtengemeinschaft/verstorbene.html.

Benzing, J. (1986). Verzeichnis der Professoren der alten Univerität Mainz. Mainz: Universitätsbibliothek Johannes Gutenberg-Unviersität.

Berger-Levrault, O. (1890). Catalogus professorum Academiarum et Universitatum alsaticarum XVI-XVIII seculi, editore Oscar Berger-Levrault. Nancy Impr. de BergerLevrault.

Berlin-Brandenburgische Akademie der Wissenschaften (2010). Historische Akademiemitglieder, http://www. bbaw.de/die-akademie/akademiegeschichte/ mitglieder-historisch.

Bianco, F. J. V. (1974). Die alte Unvirsität Köln und die späteren Gelehrten-Schulen dieser Stadt: nach archivarischen und anderen zuverlässigen Quellen, vol. 1. Aalen: Scientia-Verl.

Brants, V. (1906). La faculté de droit de l'Université de Louvain à travers cinq siècles $<1426-1906>$. Louvain: Ch. Peeters. 
ConRad, E. (1960). Die Lehrstühle der Universität Tübingen und ihre Inhaber (1477-1927). Tübingen.

Čornejová, I. and Fechtnerová, A. (1986). Životopisný slovnık Pražské Univerzity: Filozofická a Teologická Fakulta 1654 - 17r3. Praha: Univ. Karlova, 1st edn.

Dorsman, L. (2011). Catalogus Professorum Academiae Rheno-Traiectinae, http:// profs.library.uu.nl/index.php/info/project.

Drüll, D. (2009). Heidelberger Gelehrtenlexikon 1933-1986. Berlin, Heidelberg: Springer.

DrüLL, D. (2012). Heidelberger Gelehrtenlexikon 1803-1932. Berlin, Heidelberg: Springer.

Drüll-Zimmermann, D. (1991). Heidelberger Gelehrtenlexikon 1652-1802. Berlin, Heidelberg: Springer.

Drüll-Zimmermann, D. (2002). Heidelberger Gelehrtenlexikon 1386-1651. Berlin, Heidelberg: Springer.

EBEL, W. (ed.) (1962). Catalogus professorum Gottingensium: 1734-1962. Göttingen and Göttingen: Vandenhoeck \& Ruprecht and Niedersächsische Staats- und Universitätsbibliothek.

EID, L. (1926). Die gelehrten Gesellschaften der Pfalz. Speyer, Lehrerbildgsanst.: [Selbstverl.].

Feenstra, R., Ahsmann, M. and Veen, T. (2003). Bibliografie van hoogleraren in de rechten aan de Franeker Universiteit tot 1811. Amsterdam: Koninklijke Nederlandse Akademie van Wetenschappen.

Flessa, D. (1969). Die Professoren der Medizin zu Altdorf von 1580 - 1809. Universität Erlangen-Nürnberg.

Fornasin, A., Breschi, M. and Manfredini, M. (2010). Mortality patterns of cardinals (sixteenth-twentieth centuries). Population, 65 (4), 631-652.

Fourquet, É. (1929). Les hommes célèbres et les personnalités marquantes de FrancheComté: du IVe siècle à nos jours. Besançon: Séquania.

FRÖDE, T. (2017). Biographisches Lexikon der Mitglieder der Oberlausitzischen Gesellschaft der Wissenschaften: 1779-1945. Görlitz: Oberlausitzische Gesellschaft der Wissenschaften e. V. 
Gleixner, U. (2018). Professorenkatalog, http://uni-helmstedt.hab.de/index.php.

Groningen, R. (2014). Catalogus Professorum Academiae Groninganae, https:// hoogleraren.ub.rug.nl/.

Gundlach, F. and Auerbach, I. (1927). Catalogus professorum academiae Marburgensis; die akademischen Lehrer der Philipps-Universität in Marburg. Marburg: N. G. Elwert'sche Verlagsbuchhandlung G. Braun.

Gundler, B. (1991). Catalogus Professorum der Technischen Universität Carolo- Wilhelmina zu Braunschweig. Teil 2: Lehrkräfte 1877-1945. Braunschweig: Braunschweiger Hochschulbund.

GüNTher, J. (1858). Lebensskizzen der Professoren der Universität Jena seit 1558 bis 1858: Eine Festgabe zur 300-jährigen Säkularfeier der Universität am 15., 16., und 17. August 1858. Jena: Mauke.

Hänsel, W. (1971). Catalogus Professorum Rinteliensium - Die Professoren Universität Rinteln and akademischen Gymnasiums zu Stadshagen 1610-1810. Rinteln: Verlag C. Bösendahl.

Hasquin, H. (2009). L'Académie impériale et royale de Bruxelles. Ses académiciens et leurs réseaux intellectuels au XVIIIe siècle. Bruxelles: Académie Royale de Belgique.

Haupt, H. and Lehnert, G. (2006). Chronik der Universität Gießen von 1607-190\%. Gießen: Universitätsbibliothek.

Heidelberger Akademie der Wissenschaften (2019). Die Mitglieder der HAdW seit ihrer Gründung 1909, https://www.haw.uni-heidelberg.de/akademie/ mitglieder1909.de.html.

HobBs, F. (2004). Age and sex composition. In H. S. Shryock, J. S. Siegel and E. A. Larmon (eds.), The methods and materials of demography, 2nd edn., US Bureau of the Census, pp. $125-174$.

Kiefer, J. (2004). Bio-bibliographisches Handbuch der Akademie Gemeinnütziger Wissenschaften zu Erfurt: 1754-2004. Erfurt: Akad. Gemeinnütziger Wiss. zu Erfurt.

Klinge, M. (2004). Teachers. In W. Rüegg (ed.), A History of the University in Europe, Universities in the Nineteenth and Early Twentieth Centuries 1800-1945, vol. III, 5, Cambridge University Press, pp. 123-162. 
Kohnle, A. and Kusche, B. (2016). Professorenbuch der theologischen Fakultät der Universität Wittenberg: 1502 bis 1815/17. Leipzig: Evangelische Verlagsanstalt.

Krahnke, H. (2001). Die Mitglieder der Akademie der Wisenschaften zu Göttingen 17512001. Göttingen: Vandenhoeck \& Ruprecht.

Krones, F. X. (1886). Geschichte der Karl Franzens-Universität in Graz. Geschichte der Karl-Franzens-Universität in Graz: Festgabe zur Feier ihres dreihundertjährigen Bestandes, Graz: Verlag der Karl Franzens-Universität.

KrÜGer, K. (2019). Catalogus Professorum Rostochiensium, http://cpr.uni-rostock. de/.

Kurrus, T. (1977). Die Jesuiten an der Universität Freiburg im Br. 1620 - 1773, Beiträge zur Freiburger Wirtschafts und Universitätsgeschichte, Issue 37, vol. 2. Freiburg im Br.: Eberhard Albert.

LaCKNeR, F. (1976). Die Jesuitenprofessoren an der philosophischen Fakultät der Wiener Universität (1712-1773), vol. 1 \& 2. Wien: VWGÖ, Verb. d. Wissenschaftl. Gesellschaften Österreichs.

Lamberts, E. and Roegiers, J. (1990). Leuven University, 1425 - 1985. Leuven: Leuven University Press.

Ley, A. (1999). Die Professoren und Dozenten der Friedrich Alexander Unviersität 17431960: Teil 2: Medizinische Fakultät, Erlanger Forschungen Sonderreihe, vol. 9. Erlangen: Univ.-Bibliothek.

McClelland, C. E. (1988). Die deutschen Hochschullehrer als Elite 1815-1850. In K. Schwabe (ed.), Deutsche Hochschullehrer als Elite 1815-1945, Harald Boldt Verlag, pp. $27-54$.

MülleR, G. (1999). Technische Universität Clausthal: Der Lehrkörper 1775 - 1999. Hannover: Schlütersche GmbH \& Co.KG.

Napjus, J. W. and Lindeboom, G. A. (1985). De hoogleraren in de geneeskunde aan de Hogeschool en het Athenaeum te Franeker, Nieuwe Nederlandse bijdragen tot de geschiedenis der geneeskunde en der natuurwetenschappen, vol. 15. Amsterdam: Rodopi.

Nève, F. (1856). Mémoire historique et littéraire sur le Collège des trois-langues à l'Université de Louvain, vol. 28. Hayez. 
RAM, P. F. X. D. (1861). Les quatorze livres sur l'histoire de la ville de Louvain du docteur et professeur en théologie Jean Molanus: Historiae lovaniensium. Collection de chroniques belges inédites, Bruxelles: Hayez.

Rehmann, W. (2006). Chronik der Ludwigs-Universität Gießen 1907-1945 und der Justus Liebig-Hochschule Gießen 1946-195\%. Gießen: Universitätsbibliothek.

REINDL, M. (1966). Lehre und Forschung in Mathematik und Naturwissenschaften, insbesondere Astronomie: an der Universität Würzburg von der Gründung bis zum Beginn des 20. Jahrhunderts. Degener und Company.

Ruth, H. (2001). Das Personen- und Ämtergefüge der Universität Freiburg (1520-1620). Bd. I: Darstellung, Diss.

Sächsische Akademie der Wissenschaften ZU Leipzig (2019). Mitglieder, https: //www.saw-leipzig.de/de/mitglieder.

Schleiff, H., Volkmer, R. and Kaden, H. E. (2015). Catalogus Professorum Fribergensis: Professoren und Lehrer der TU Bergakademie Freiberg 1765 bis 2015. Freiberg: Verlag TU Bergakademie.

Svatoš, M. (1995). Dějiny Univerzity Karlovy I., 1347/48 - 1622, Dějiny Univerzity Karlovy 1348 - 1990, vol. 1. Praha: Univ. Karlova.

Tricot-Royer, J. J. (1927). Coup d'oeil sur l'ancienne faculté de médecine de Louvain. F. Ceuterick.

UniversitAiRE BiBliotheKEn LEIDEN (2019). Leidse hoogleraren vanaf 1575, https: //hoogleraren.leidenuniv.nl/.

Universitätsarchiv Bamberg (2019). Bamberger Professorinnen- und Professorenkata$\log$, mimeo.

Universitätsarchiv Marburg (2019). Marburger Professorenkatalog, https://www . uni-marburg.de/uniarchiv/pkat/.

University of Amsterdam (2007). Album Academicum, http://www. albumacademicum.uva.nl/.

Valentiner, S. (1925). Die Preußische Bergakademie zu Clausthal 1775/1925: Festschrift zur 150-Jahrfeier. Leipzig: Breitkopf \& Härtel. 
VAN DE KAA, D. J. and Roo, Y. D. (2008). De Leden Van De Koninklijke Nederlandse Akademie Van Wetenschappen: Een Demografisch Perspectief: 1808 tot 2008. Amsterdam: KNAW Press.

VAN EPEn, D. G. (1904). Album studiosorum Academice gelro-zutphanicae MDCXLVIIIMDCCCXVIII. Hagae Comitis: apud Jacobum Hoekstra.

Vandermeersch, P. A. (2003). Teachers. In H. De Ridder-Symoens (ed.), A History of the University in Europe, Universities in Early Modern Europe 1500-1800, vol. II, 5, Cambridge University Press, pp. 210-255.

Verger, J. (2003). Teachers. In H. De Ridder-Symoens (ed.), A History of the University in Europe, Universities in the Middle Ages, vol. I, 5, Cambridge University Press, pp. $144-168$.

Volbehr, F. and Weyl, R. (1956). Professoren und Dozenten der Christian-AlbrechtsUniversität zu Kiel: 1665 - 1954. Kiel: Hirt.

VON Hehl, U. and Riechert, T. (2017). Catalogus Professorum Lipsiensium, https: //research.uni-leipzig.de/catalogus-professorum-lipsiensium/.

Wachter, C. (2009). Philosophische Fakultät, Naturwissenschaftliche Fakultät, Erlanger Forschungen Sonderreihe, vol. 13. Erlangen: Univ.-Bibliothek.

Walter, L. K. (2010). Dozenten und Graduierte der Theologischen Fakultät Würzburg 1402 bis 2002. Würzburg: Schöningh.

Wedel-Schaper, E. and Wittern, R. (1993). Die Professoren und Dozenten der Friedrich-Alexander-Universität Erlangen-Nürnberg 1743-1860: Teil 1: Theologische Fakultät, Juristische Fakultät. Erlangen: Univ.-Bibliothek.

Wenig, O. (1968). Verzeichnis der Professoren und Dozenten der Rheinischen FriedrichWilhelms-Universität zu Bonn 1818-1968. Bouvier. 